\title{
Augmenting the Role of Tourism Governance in Addressing Destination Justice, Ethics, and Equity for Sustainable Community-Based Tourism
}

\author{
Tek B. Dangi ${ }^{1, *}$ and James F. Petrick ${ }^{2}$ \\ 1 Department of Exercise, Health and Sport Sciences, University of Southern Maine, Portland, ME 04104, USA \\ 2 Department of Recreation, Park and Tourism Sciences, Texas A\&M University, \\ College Station, TX 77843, USA; jpetrick@tamu.edu \\ * Correspondence: tek.dangi@maine.edu or tekdangi@gmail.com; Tel.: +1-(207)-780-4587
}

Citation: Dangi, T.B.; Petrick, J.F. Augmenting the Role of Tourism Governance in Addressing Destination Justice, Ethics, and Equity for Sustainable Community-Based Tourism. Tour. Hosp. 2021, 2, 15-42. https:// doi.org/10.3390/tourhosp2010002

Received: 16 November 2020 Accepted: 23 December 2020 Published: 1 January 2021

Publisher's Note: MDPI stays neutral with regard to jurisdictional clai$\mathrm{ms}$ in published maps and institutional affiliations.

Copyright: (C) 2021 by the authors. Licensee MDPI, Basel, Switzerland. This article is an open access article distributed under the terms and conditions of the Creative Commons Attribution (CC BY) license (https:// creativecommons.org/licenses/by/ $4.0 /)$.

\begin{abstract}
Sustainable tourism development (STD) serves as a founding and guiding concept that can be applied to all forms of tourism, whereas community-based tourism (CBT) has been largely practiced as an alternative form of tourism development. Past research has suggested critical theoretical and practical omissions in both STD and CBT related to issues of community well-being, justice, ethics, and equity. With an objective of bridging these gaps, this research developed an integrated framework of sustainable community-based tourism (SCBT) based on a comprehensive literature review, which identified that there was a significant under-representation of key elements such as justice, ethics, and equity in the domain of governance both in the STD and CBT literatures. The qualitative research mixed emergent data with theory driven data and conducted semi-structured interviews with 40 diverse tourism stakeholders in the twin cities of Bryan-College Station (BCS) in Texas. Results revealed that tourism helped to promote cultural preservation and community pride and promoted the sense of mutual respect and understanding among visitors and stakeholders. However, some ethnic minorities felt they were not receiving full benefits of tourism. The study concluded that a more proactive, inclusive, ethic of care oriented tourism governance to help ensure sustainable tourism development is needed.
\end{abstract}

Keywords: sustainable tourism; community-based tourism; tourism governance; destination justice; ethics; equity; tourism stakeholders

\section{Introduction}

Sustainable tourism (ST) development has long been promoted and practiced as an alternative model of tourism development that seeks balanced development while minimizing social, cultural, and environmental impacts of tourism [1-4]. Various forms of alternative tourism including ecotourism, rural tourism, community-based tourism, agrotourism, volunteer tourism, and responsible tourism have remained in practice since 1980s as an adaptancy approach to sustainable tourism development [5-8]. Much literature has been published in the past four decades delineating sustainable tourism (ST) development and community-based tourism (CBT). ST has been claimed to be originated by international organizations such as the United Nations (Earth Summit), United Nations Environment Program (UNEP), United Nations World Tourism Organization (UNWTO), and the World Travel and Tourism Council (WTTC) $[9,10]$, while CBT has been claimed to have origins at various local and regional scales spanning across different countries and continents around the world $[9,11,12]$.

However, scholars have suggested that the road to sustainable tourism development has not been straight-forward, including conceptual, implementation, and governance challenges [1,13-19]. Further, despite the availability of a plethora of definitions, principles, indicators, criteria and practices related to ST and CBT, there remains little guidance how 
these diverse perspectives can be integrated to "help inform a sustainability-oriented approach to tourism" [20] (p. 1). Jamal, Camargo, and Wilson [10] outlined the need "to develop a comprehensive framework of justice and care to guide and evaluate sustainable tourism" (p. 4606).

In order to address the issue pointed out by Jamal, Camargo, and Wilson [10] and Jamal and Camargo [21], a preliminary framework of "Sustainable Community-Based Tourism" (SCBT henceforth) was developed (for details see [20] (pp. 65-68) by conducting a comprehensive literature review (CLR) both on ST and CBT in order to bridge the existing gap (more details on CLR in literature review section). The CLR identified that three dimensions of sustainable development, economic, social-cultural, and environmental, were given impetus by a majority of scholars and institutions, including [4,22,23]; however, the fourth dimension/domain of sustainability-governance, though ignored by many, has been emphasized by other scholars, including [17,24-26], in the form of governance, institutional arrangements, or as political/administrative environments. Further, other scholars including $[10,15,27,28]$ have suggested that salient issues of justice, ethics, and equity related to governance have been largely ignored or found misrepresented in both ST and CBT settings.

The research argues that the critical elements of justice, ethics, and equity within the dimension of governance have been under-examined in both the ST and CBT literatures. Inclusion of such issues could help tourism planners and practitioners make decisions that are more oriented towards overall community wellbeing and that align with the principles of Theory of Justice (Rawls [29,30]), justice tourism, and ethical tourism. Taking those existent issues into consideration, the research had purposes (i) to explore (through a CLR) the elements of destination justice, ethics, and equity in the domain of tourism governance and propose an integrated framework of SCBT; (ii) to conduct an empirical study in Bryan-College Station (BCS) tourism community, TX, USA applying some SCBT criterions for exploring the elements of justice, ethics, and equity within the dimension of governance.

\section{Literature Review Leading to SCBT Framework}

In order to develop a robust framework and approach to SCBT, an in-depth and comprehensive literature review (CLR) was conducted aiming to trace the history and common and contrasting elements relating to the definitions, principles, concepts, and critical success factors of ST and CBT development and to explore gaps therein as suggested by earlier studies $[10,21]$. The CLR followed some of the steps suggested by Arksey and O'Malley [31] and Grant and Booth [32] for the scoping review process. Buckley [33] and Arksey and O'Malley [31] suggested that a scoping review could be undertaken in the same fashion as an exploratory literature review through the systematic application of key search terms. Therefore, the CLR replicated the techniques of scoping review suggested by Grant and Booth [32] and included the steps of search, appraisal, synthesis, and analysis (SALSA). The systematic literature review was conducted in two phases from June 2014 through spring 2016. The initial search was conducted in June 2014 applying the commercial literature database Business Source Complete. The terms used in the search process included "sustainable tourism; community-based tourism; responsible tourism; (sustainable tourism) (community based tourism) framework/model/criteria/indicators/principles/definitions/certifications" [34] (p. 475). Another expanded, but focused, search was conducted in the Scopus database (in spring 2016) applying a similar procedure aforementioned. However, this search also explored domains of governance including issues such as justice, ethics, and equity. Overall, around 260 peer reviewed journal articles, book chapters, and seminal conference papers in English language received full review; though all were not considered worthy for references (For details on CLR, please see [20,34]). Further, to make the literature review current, a review of sixteen additional peer-reviewed journal articles and book chapters was conducted in 2020 and added in the research. The CLR made an in-depth exploration of the history 
of sustainable development, its bearing on $\mathrm{ST}$ and $\mathrm{CBT}$, with focused search on tourism governance, justice, ethics, and equity which are presented below with some details.

\subsection{History—The Emergence of "Sustainable Development"}

Presumably, the first official definition of sustainable development (SD) was forwarded by the World Commission on Environment and Development (WCED), defining SD as, "development that meets the needs of the present without compromising the ability of future generations to meet their own needs" [35] (p. 8). Sustainability seemed to emerge as a central theme and a guiding principle for development for governments, businesses, and other private organizations, following the WECD initiative. The notion of sustainability, however, had existence in both theory and practice long before this event. Publications such as Club of Rome's report "The Limits to Growth", 1972 [36], and the first United Nations Conference on the Human Environment, Stockholm, 1972 [37] (para. 1) seem to serve as the forerunners for sustainable development. Hardy, Beeton, and Pearson [38] suggested that the Stockholm conference promoted the concept of integrated eco-development where cultural, social, and ecological goals were interwoven together, requiring equal and serious consideration in the development agenda.

The 1972 United Nations Educational, Scientific, and Cultural Organization (UNESCO) Convention forwarded an official definition of the world's natural and cultural heritage sites and made state parties accountable to the protection and conservation of UNESCO World Heritage sites [39]. Hall, Gossling, and Scott [40] contended that in WECD's (1987) report, sustainable tourism did not receive a high priority; however, it has become "one of the great success stories of tourism research and knowledge transfer" (p. 2) in the succeeding decades thereafter.

The UN Conference on Environment and Development (UNCED), popularly termed as "Earth Summit", held in Rio de Janeiro (June 1992) produced a constitution of sustainable development known as "Agenda 21" [41]. As a comprehensive program of action, Agenda 21 was adopted by 182 governments at the UNCED conference. Though not legally binding, "Agenda 21 carries moral and practical suggestions for consideration ... (which) is considered a blueprint for sustainable development in the 21st century" [20] (p. 14). Further, declaration of United Nations' eight Millennium Development Goals-MDGs (2000-2015) and adoption of 17 Sustainable Development Goals (SDGs) by United Nations in 2015 have made a "universal call to action to end poverty, protect the planet, and ensure that all people enjoy peace and prosperity by 2030" [42] (para. 1), adding momentum to the journey to sustainability.

Sustainable tourism development, as a sub-sector of sustainable development, endeavors to minimize the adverse socio-cultural and environmental impacts while enhancing the opportunities for community income, community well-being, and visitors' satisfaction [12,14,43]. Graci and Dodds [44] suggested the UNCED conference (1992) identified tourism as "one of the five main industries in need of achieving sustainable development" (p. 11). The World Summit on Sustainable Development (2002) emphasized poverty alleviation as a priority area while developing an implementation plan for sustainable development [4] when close ties emerged between poverty and environmental degradation.

\subsection{Emergence of Sustainable Tourism Development (STD)}

There is evidence that joint institutional endeavors for STD took place earlier than the WECD [35] initiatives. For example, an alliance emerged between UNESCO and the World Bank in 1970s in the area of heritage conservation and financing of tourism infrastructure development. As a joint initiative of these two organizations, a seminar was convened in 1976 "to discuss the social and cultural impacts of tourism on developing countries and to suggest ways to take account of these concerns in decision-making" [45] (p. ix). However, tourism did not receive an early recognition as one of the major sectors in sustainable tourism development. Hall, Gossling, and Scott [40] suggested that tourism could not draw much attention in the WECD (1987) report. However, following the joint 
publication of Agenda 21 for the Travel and Tourism Industry: Towards Environmentally Sustainable Development [2] by UNWTO, WTTC, and the Earth Summit (EC) in 1995, sustainable tourism development received wider publicity and planning impetus. This report noted that while Agenda 21 (product of Rio Summit, 1992) recognized the potential of low-impact nature-based tourism (ecotourism) enterprises (underestimating the size and significance of travel and tourism industry), Agenda 21 for the travel and tourism industry underlined the urgency of making all travel and tourism operations sustainable, detailing priority areas and guidelines for governments and the tourism industry. The UNEP-UNWTO [4] report and other scholarly works [46,47] identified major stakeholders including tourism enterprises, local communities, tourists, and governments that are accountable for the sustainability of tourism businesses.

The UNEP-UNWTO report [4] presented a broader definition of sustainable tourism:

Sustainable tourism development guidelines and management practices can be applied to all forms of tourism, for all types of destinations, including mass tourism and various niche tourism segments [4] (p. 11).

The UNEP-UNWTO report [4] emphasized three pillars of STD—economic, social, and environmental-combined with 12 aims. The 12 aims were identified as economic viability, local prosperity, employment quality (within the economic pillar); social equity, visitor fulfillment, local control, community wellbeing, and cultural richness (within the social pillar); and physical integrity, biological diversity, resource efficiency, and environmental purity (within the environmental pillar) [4] (p. 9). Further, various institutions and scholars have forwarded principles integral to STD including holistic planning and strategymaking, preserving essential ecological processes, protecting both human heritage and biodiversity, sustaining productivity over the long term for future generations, pursing multi-stakeholder engagement, addressing global and local impacts, and considering the issues of equity in tourism operations $[1,3,4]$.

\subsection{CBT and Other Alternative Tourism Approaches to STD}

Departing from the Advocacy platform [48] of tourism popularized during the 1950s-1960s that tourism is a viable option for development with few negative impacts, the Cautionary platform of tourism (1970s) suggested that tourism can also bring negative impacts to destinations if they are not carefully planned. The Adaptancy platform of tourism was popularized in the 1980s, which favored alternative forms of tourism such as CBT, ecotourism, geo-tourism, responsible tourism, and volunteer tourism in place of mass tourism for destination sustainability $[12,49,50]$. Some of the characteristics of alternative tourism include small size operations, benefitting local people and communities, owned and managed by local residents or community, sensitive to environment, understanding of local culture, heritage and tradition, and poverty reduction through Pro-Poor Tourism (PPT) schemes $[3,5,6,10]$. A table is presented below that defines various forms of alternative tourism under the over-arching umbrella of STD (Table 1). 
Table 1. Defining ST, CBT, and various alternative forms of tourism.

\begin{tabular}{ll}
\hline & Definition \\
\hline Sustainable tourism & $\begin{array}{l}\text { "Tourism that takes full account of its current and future economic, social and environmental impacts, } \\
\text { addressing the needs of visitors, the industry, the environment, and host communities" [4] (p. 12). }\end{array}$ \\
\hline $\begin{array}{l}\text { Community-Based } \\
\text { Tourism }\end{array}$ & $\begin{array}{l}\text { "CBT is generally small scale and involves interactions between visitor and host community, } \\
\text { particularly suited to rural and regional areas. CBT is commonly understood to be managed and } \\
\text { owned by the community, for the community" [50] (p. 2). }\end{array}$ \\
\hline Ecotourism & $\begin{array}{l}\text { "Responsible travel to natural areas that conserves the environment, sustains the well-being of the } \\
\text { local people, and involves interpretation and education" [51] (para.1). }\end{array}$ \\
\hline "Teotourism & $\begin{array}{l}\text { Tourism that sustains or enhances the distinctive geographical character of a place-its environment, } \\
\text { heritage, aesthetics, culture, and the well-being of its residents" [52] (para. 1). }\end{array}$ \\
\hline Responsible Tourism & $\begin{array}{l}\text { "Tourism that puts those people living in poverty at the top of the agenda. PPT strategies are } \\
\text { concerned with reducing both absolute and relative poverty by providing tourism-related income } \\
\text { opportunities for disadvantaged groups" [54] (p. 10). }\end{array}$ \\
\hline Pro-Poor Tourism & $\quad$ Sourism is about "making better places for people to live in and better places for people \\
\hline
\end{tabular}

Source: Adapted from Dangi [20] (p. 25).

\subsection{Dimensions of Community-Based Tourism (CBT)}

CBT is one of the extended functional aspects of "Community" and has been suggested to have three common elements: (1) a geographical area/a locality, (2) common ties/bonding among its people, and (3) social interactions/collective actions $[55,56]$. Warren [57] defined community as a shared living based on the common geographical location of the individuals, the larger society, and culture. He also presented six approaches for the study of community: (1) community as a space (applied both in Rural and Urban Community studies), (2) community as people, (3) community as shared institutions and values, (4) community as interaction, (5) community as a distribution of power, and (6) community as a social system. Similar to other areas of community engagement such as education, health, infrastructure development, and social services, "CBT shows obvious parallels with broader community development and participatory planning philosophies" [58] (p. 40).

Mtapuri and Giampiccoli [59] presented various modalities of CBT projects and stated they could be initiated from within and outside the community, led by public, private, and non- governmental agencies or a combination of those applying a top-down or bottom-up approach. On the basis of market priority, bottom-up CBT approaches have typically been associated with domestic/local markets, whereas top-down CBT approaches have typically been associated with international markets [59]. Irrespective of forms and shapes, scales, and geographical locations, common objectives of CBT operations include improving local economies, sharing social-economic benefits equitably, environmental conservation, preservation of local culture and heritage, empowerment and ownership of local businesses, and ensuring quality and authentic experience for visitors $[12,20,50,59]$. In some instances, CBT objectives can be more focused, such as "both poverty reduction and community development [59] (p. 155) and "redistribution of economic benefits among the most vulnerable of groups, such as indigenous communities" [12] (p. 2).

CBT is believed to have started "in the early 1980s as the sine qua non of alternative tourism" [8] (p. 206). As an alternative to mass tourism [8,20,50,59], CBT emerged in the context of helping rural communities in the developing world through grassroots development, community empowerment and participation, and capacity enhancement of the local people (see $[60,61])$. However, evidences suggest that CBT practices can also be found in developed economies in the North, such as Canada during the 1980s [62,63]. Mtapuri and Giampiccoli [59] stated, "Canada's Northwest territories Government was possibly the first government to advance a CBT development strategy in its territory" (p. 155). CBT as an approach to STD has been practiced all over the world [12,59]. The CLR also found that some terminologies such as "Rural Tourism" have often been used 
alongside CBT in Latin America and other developed nations and alongside "Ecotourism" in Asia. It has further been suggested that sustainable tourism, CBT, rural tourism, and ecotourism carry identical objectives [50].

It was an interesting exploration during the CLR that a number of "critical success factors" (CSFs) for CBT were observed that are common both in the developed and developing countries. Those CSFs were categorized into four key dimensions of community empowerment as proposed by Scheyvens $[60,61]$ and supported by other scholars $[49,64,65]$. The four dimensions of community empowerment Scheyvens [60] mentioned include economic empowerment, psychological empowerment, social empowerment, and political empowerment [60,61]. Basic elements of CSFs presented by various authors include engagement/participation, community assets, collaboration, cultural and heritage preservation, equity and local ownership, economic benefits, empowerment, leadership, and job opportunities. Environmental protection and management and infrastructure development are other salient factors $[66,67]$ of CBT not to be ignored. These CBT success factors served as guiding resources in developing a preliminary framework of SCBT.

\subsection{Comparing ST and CBT: Similarities and Differences}

The CLR revealed both commonalities and subtle differences between ST and CBT. No considerable variations were found relating to their aims and objectives; rather, CLR revealed that "CBT incorporates the objectives of sustainable tourism with an emphasis on community engagement and development" [68] (3), and it incorporates the dimensions of local control and management of business for poverty reduction and providing the community with supplemental means of income [54]. Further, most scholars believe that in the absence of uniform principles of CBT, ST principles apply to community settings similar to other alternative forms of tourism. It has also been claimed that as overarching concepts, ST principles apply to all forms of tourism including mass tourism or CBT $[4,38,69]$. Another common ground seemed to be that both ST and CBT are promoted by international and non-governmental agencies including the World Bank and Global Environmental Facility [70].

Regarding differences, the CLR found that ST principles primarily originated from international public-private organizations including the United Nations' Earth Summit, UNEP, UNWTO, and WTTC, and from tourism scholars and critics mainly from the West $[9,10,16,19,43]$. CBT, as an alternative to mass tourism, was found to emphasize grassroots development through participation, equity, and empowerment with an emphasis on small and medium-scale projects mostly owned by local businesses [12]. Further, another difference between ST and CBT remains that for "CBT operations, communities (hosts) and tourists (guests) have more mutually beneficial relationships: CBT projects are designed so that benefits/dividends rotate and/or are allocated among residents, and CBT initiatives are initiated by a family or a group based on community assets, sometimes joined by outside business partners" [20] (p. 40). Application of these principles supports retaining economic benefits and enhancing community well-being. Viewed from this perspective, CBT intersects with responsible tourism (RT), as it "benefits local community, natural and business environment and itself" [71] (p. 314). Judged from these perspectives, CBT and ST are neither fully similar nor dissimilar, but possess substantial intersections and overlaps as two focused approaches to tourism development. These findings suggest ST is more of an overarching concept, whereas CBT is a form/approach to tourism development rooted in the locale/community.

\subsection{Critique of ST and CBT}

It can be argued that the use of sustainable development objectives with institutional guidance (e.g., the UN and its specialized agencies) to monitor progress has been extremely beneficial. Yet, it has been argued they have failed to meet the goals and objectives within the set time-frame and do reframe sustainability goals for future events and conferences such as MDGs and SDGs [19,72]. Mahanti and Manuel-Navarrete [73] charged that the 
noble concept of SD has been downgraded due to "the meager performance of Rio+20 'landmark' conferences" (p. 417). Garrod and Fyall [13] charged, "Defining sustainable development in the context of tourism has become something of a cottage industry in the academic literature of late" (p.199). Further, STD has been labelled as greenwashing for its failure in balancing social and environmental issues while over emphasizing economic gains. It has also been charged for largely ignoring local voices and not adequately addressing the issues of equity, social justice, and equitable distribution of benefits. Johnston [74] stated that significant theoretical and practical gaps were visible with regard to sustainable tourism research and practices. Even CBT seems to have developed dependency on international markets, global capital, and expertise, though its premise was initially built on local values and empowering communities. To conclude, it can be stated that the ST principles are transferable to CBT research and practice settings (or vice-versa). However, a minute observation of the extant scholarship in the field presents some theoretical/conceptual, implementation, and governance challenges and omissions of justice, ethics, and equity in the domain of governance.

\subsection{CLR Summary on ST and CBT and Identification of Gaps}

The literature review provided a systematic and chronological history of sustainable tourism development and its various forms including CBT. Review of critical success factors (CSFs) of CBT and analysis of various criteria and dimensions of ST and CBT led to the acknowledgement of well-represented aspects and existing gaps. As stated earlier, the CLR revealed that three dimensions/pillars of sustainability: economic, social-cultural, and environmental, have been emphasized by the majority of scholars and institutions including $[4,22,23,75]$; however, the fourth dimension of sustainability-governance, though ignored by many, was emphasized by other scholars including [17,24-26,76-79] in the form of governance, institutional arrangements, or as political/administrative environments (for details see [34] (p. 14). The CLR further revealed that a significant number of scholars including $[10,15,27,28]$ (as detailed in Table 2) proposed that issues of ethics, justice, and equity in the domain of governance received less attention or they were largely ignored.

Jamal, Camargo, and Wilson [10] suggested the need for "a clear framework of justice and ethics" (p. 4594) for sustainable tourism, and this study attempted to address the issue through an empirical study (case study) of the BCS tourism community. Jamal [80] stated that justice is a pluralistic and complicated concept, and it is not easy to separate justice from ethics. It is worth mentioning that in their recent work, Jamal and Camargo [81] reemphasized "justice as a key principle for good governance and policy in tourism" (p. 205). Further, in their very recent (2020) work on justice and ethics, Jamal and Higham [82] claimed "The subject of justice in tourism and hospitality studies is indeed slowly being advanced by the academic community, alongside closely related areas of ethics" (p. 147), underlining the need of further studies/research in this area. Further, Jamal and Higham [82] presented a conceptual, holistic, and interrelated (yet partial and processual) model of Justice and Tourism, wherein they described emerging principles and approaches to Justice and Tourism, which included (1) social justice, equity, and rights; (2) inclusiveness and recognition; (3) sustainability and conservation; (4) well-being, belonging, and capabilities; (5) posthumanistic justice; and (6) governance and participation. Guia's [83] recent (2020) work on justice tourism proposed four ethical approaches to tourism and justice study and research. This is how past and current research lead to a direction that issues of justice, ethics, and equity and other interrelated emerging approaches are in need of further exploration, which signifies the context and importance of what the current research investigated. Drawing upon the CLR (both past and current), the research developed a preliminary framework of SCBT, as presented in Table 2 below. To serve the purpose of this research, the dimension of governance and critically under-represented issues such as justice, ethics, and equity under the domain of governance are detailed in Table 2 below. 
Table 2. Combined (Preliminary) framework of SCBT with available criteria.

\begin{tabular}{|c|c|c|}
\hline Dimensions & $\begin{array}{l}\text { Summary of SCBT Criteria/Themes Combined from } \\
\text { Various Sources * }\end{array}$ & Source/Authors \\
\hline Economic & $\begin{array}{l}\text { Economic Benefits; Local Jobs and Participation; } \\
\text { Institutional Mechanism to Ensure Economic Benefits; } \\
\text { Visitor Management. }\end{array}$ & $\begin{array}{l}\text { * For details see [20] (pp. 65-68), } \\
\&[34] \text { (pp. 17-20). }\end{array}$ \\
\hline Environmental/Ecological & $\begin{array}{l}\text { Protection of Natural Environment; } \\
\text { Reducing Waste/Emissions; } \\
\text { Innovating Adapting to Environment-friendly Plans; } \\
\text { Assessment and Monitoring. }\end{array}$ & $\begin{array}{l}\text { * For details see [20] (pp. 65-68), } \\
\&[34] \text { (pp. 17-20). }\end{array}$ \\
\hline Social-cultural & $\begin{array}{l}\text { Community Wellbeing \& Satisfaction; } \\
\text { Community Participation \& Empowerment; } \\
\text { Visitor Satisfaction. }\end{array}$ & $\begin{array}{l}\text { * For details see [20] (pp. 65-68), } \\
\&[34] \text { (pp. 17-20). }\end{array}$ \\
\hline Governance & $\begin{array}{l}\text { Planning/Strategic Vision; } \\
\text { Management \& Marketing; } \\
\text { Power, Rules \&Regulations; } \\
\text { Visitor Safety \& Crisis Management; } \\
\text { Collaboration/Coordination; Participation; Service Delivery; } \\
\text { Accountability; Transparency; Equity; Communication; } \\
\text { Leadership; Political; Technological. }\end{array}$ & $\begin{array}{l}\text { * For details see [20] (pp. 65-68), } \\
\&[34] \text { (pp. 17-20). }\end{array}$ \\
\hline Dimensions & $\begin{array}{l}\text { Summary of SCBT Criteria/Themes (with details) combined } \\
\text { from various sources }\end{array}$ & Source/Authors \\
\hline $\begin{array}{l}\text { Under-represented issues of } \\
\text { Justice, Ethics and Equity } \\
\text { (In the domain of governance) }\end{array}$ & $\begin{array}{l}\text { Justice in Tourism, Good-Action \& Virtuous Tourism: } \\
\text { Inter-and intragenerational equity; equitable distribution of } \\
\text { costs and benefits, goods and services; distributive justice } \\
\text { benefiting disadvantaged populations; respect and } \\
\text { recognition of diverse values; north-south equity, } \\
\text { self-determination and autonomy of indigenous people; } \\
\text { environmental and social-cultural justice; destination } \\
\text { justice; address discrimination, racism, inclusiveness, } \\
\text { human rights, etc. } \\
\text { Equity and Fairness: } \\
\text { Fair distribution of goods and resources; equal employment } \\
\text { opportunity (EEO) for all including women, youth, disabled } \\
\text { and vulnerable population; poverty reduction; gender } \\
\text { equity and social inclusion; fair wages and employment; } \\
\text { respect and enable human rights; affordability and access } \\
\text { (services targeted to low income, poor and } \\
\text { disadvantaged populations). } \\
\text { Related ethical issues: } \\
\text { Understanding and applying moral/ethical principles in } \\
\text { tourism; address intrinsic and instrumental values: } \\
\text { utilitarian ethics; virtue ethics; respect for persons: } \\
\text { Categorical Imperative (Kant), Ethics and the “Other"; } \\
\text { feminist ethics, ethic of care, etc." [20] (p. 68), \& [34] (p. 20). }\end{array}$ & {$[10,15,21,27,28,54,84-93]$} \\
\hline
\end{tabular}

Source: * Adapted from [20] (pp. 65-68), \& [34] (pp. 17-20).

\subsection{Theoretical and Conceptual Perspectives for the Empirical Study}

Identification of under-represented, yet critical, aspects of ST/CBT such as justice, ethics, and equity in the domain of governance through the CLR directed the study to explore conceptual foundations of the issues under investigation. The conceptual and theoretical perspectives guiding the empirical study are presented below.

Rawls' Theory of Justice: In A Theory of Justice, Rawls [29] came up with a notion of justice known as Justice as Fairness (JAF). JAF is theorized as a major departure from the normative, Anglo-American utilitarian ethic that champions for actions to be morally right if the majority of people benefit. 
JAF, on the contrary, "follows the tradition of Plato and Aristotle and emphasizes a quality of society and quality of persons through reciprocity and a system of cooperation, which is never aimed at perfection" [20] (p. 73). Rawls [29] claimed JAF to be superior to dominant utilitarian ethics. Further, Rawls' "liberal view of society and democracy emphasizes basic equal rights and liberties and fair equality of opportunity for all" [20] (73). Rawls' $[29,30]$ two principles of justice are presented below:

(a) Each person has the same indefeasible claim to a fully adequate scheme of equal basic liberties, which scheme is compatible with the same scheme of liberties for all; and

(b) Social and economic inequalities are to satisfy two conditions: first they are to be attached to offices and positions open to all under conditions of fair equality of opportunity; and second, they are to be to the greatest benefit of the least-advantaged members of society (the difference principle)" [30] (pp. 42-43).

Rawls' [30] explained that, "the first principle is prior to the second; also, in the second principle, fair equality of opportunity is prior to the difference principle" (p. 43). Rawls' emphasized the need of a basic structure of society (that can be associated to governance or institutional mechanism) to facilitate these two principles into action. Jamal found Rawls's justice as fairness to be an "ideal theory of (perfect) justice situated within a liberal social contract tradition. It is oriented towards setting up perfectly just institutions and equity and fairness in distributing society's basic goods" [80] (p. 34) suited to liberal democratic societies.

Governance: Various forms and scales of governments have been discussed and suggested in tourism literature. From the perspectives of STD, Bramwell [17] defined governance as, "in order to develop and apply policies for tourism in destinations, there is usually a requirement for knowledge, thought, the application of power, resources and rules, and also coordination and cooperation among numerous actors. Together, these are key features of governance" (p. 459).

Justice in Tourism: Higgins-Desbiolles [27] suggested that justice tourism "seeks to reform the inequities and damages of contemporary tourism ... to chart a path to a more just global order" (p. 345). Though various forms of justice have been discussed in the literature; this study focuses two types of justices—distributive and procedural. Distributive justice ensures a fair and equitable (not equal) distribution of social and economic benefits among the members in the community/society, and procedural justice creates a mechanism for fair and just participation by the members of the community/society in decision-making processes that affect them [88,94]. Adding to the definition of justice/ethical tourism, Jamal stated, "Good tourism is tourism that is just, fair, and equitable, and contributes to the well-being of human beings and nonhuman others" [80] (p. 50), including cultural well-being.

Ethics in Tourism: The margin of contrast between justice tourism and ethical tourism seems small, as rightly described by Jamal, "Justice, it turns out, is a complicated notion. It's not even easy to separate it from ethics" [80] (p. 28). Ethics has been defined as just and good action in tourism, which recognizes and respects the interest of other community members. Hultsman [85] defined ethics "as philosophical inquiry into values, and as practical application of moral behavior" (p. 554) that is virtuous, moral, and ethical. Jamal and Menzel [89] and Tribe [86] followed the notion of phronesis from Aristotle to better understand ethics in tourism, which included: "knowledge; 'the good'; actions, practice and experience; and disposition" [86] (p. 314). Highlighting the significance of ethics in sustainable tourism, Macbeth [87] attested that "Ethics is a simple imperative for living a moral life: informing all actions are ethical distinctions and decisions, values" (p. 963).

Equity/Fairness: Sharpley [3] defined equity as "development that is fair and equitable and which provides opportunities for access to and use of resources for all members of all societies, both in the present and future" (p. 8). Further, UNEP-UNWTO [4] defined social equity as "a widespread and fair distribution of economic and social benefits from 
tourism throughout the recipient community, including improving opportunities, income and services available to the poor" (p. 18).

Ethic of Care: The notion of ethic of care seeks a balance between humans and their socio-cultural environment, which originated from the work of justice tourism [90]. Smith and Duffy [15] argued for the inclusion of ethics of care to supplement justice and fairness for good governance. Jamal, Camargo, and Wilson [10] argued ethic of care denotes "respect for diversity, recognition of difference ... support of social differentiation and diversity, sympathy, mercy, forgiveness, tolerance, and inclusiveness" (p. 4606). Guia's [83] recent (2020) study of justice tourism presented four ethical approaches to tourism and justice: (1) utilitarian ethics (neoliberalism), (2) deontological/duty ethics (social liberalism), (3) ethics of care (humanitarianism), and (4) affirmative ethics (posthumanism). Application of the first was argued to contribute to unjust tourism, the second to sustainable tourism, whereas the third and fourth contributed to justice through tourism and justice tourism, respectively. Further, Guia (2020) defined ethics of care as "the moral principles of care and benevolence" [83] (p. 509), guided by virtue and based on interpersonal relations.

Based on the foundations of CLR, following the framework of SCBT proposed, and guided by theoretical and conceptual underpinnings relating to the principles of governance, ethics, justice, equity, and ethic of care, the study developed the following primary research question to explore the under-represented issues of justice, ethics, and equity in the domain of tourism governance in BCS, TX:

Research Question: How do the various stakeholders feel about tourism development in BCS, specifically, with respect to the distribution of tourism related goods and resources (Distributive Justice), and with respect to ethic of care?

The study asked each participant the following semi-structured interview questions:

1. How are tourism revenues (receipts?) and goods (benefits) being distributed among the tourism industry?

(a) Mechanisms for distribution? Who gets what?

(b) Do you believe tourism revenues have been distributed fairly among the tourism industry stakeholders? Were there financial incentives and opportunities to encourage locals to own and operate their own tourism-related businesses?

(c) Did tourism workers in BCS receive a fair wage (in relation to living standards and wages)? Should more be done to provide a "living wage"?

(d) How were the minority operated tourism businesses and attractions faring? Should they get more assistance from tourism revenues and benefits in BCS?

(e) Are there financial or other incentives (or special programs) for enabling lower income groups and residents (e.g., minority populations) to engage in tourism development?

(f) Overall costs and benefits: Are the costs and benefits of tourism to BCS being fairly distributed? Do you feel you are getting a fair share of the overall benefits? How are the residents benefitting? How are minority populations and low income residents benefitting from tourism?

(g) Who decides how the tourism revenues/benefits are to be distributed? (Government and CVB, but what role does the local industry play here?)

2. How much attention is being paid to fostering cultural pride and respect for the diverse cultural groups (residents) and traditions in BCS (through tourism)?

3. What do you (and other service providers) do to educate the visitors about the diverse history and culture of BCS?

\section{Materials and Methods}

\subsection{Study Context}

The two adjoining cities of Bryan-College Station (BCS) located in Brazos County, Texas, are both homes to higher education institutions. TAMU is one of the largest public universities in the world, which was established in 1876, while Blinn was established in 
1883 in Bryan. Further, Texas A\&M sports, such as college football, baseball, basketball, and softball, combined with various attractions in the twin cities such as annual cultural events and festivals, George Bush Presidential Library and Museum, and historic downtown Bryan add significance to this place as a tourism destination. Texas A\&M's academic events including Graduation Days, Parents' Weekends, and Ring Days attract a significant number of visitors from student family members and the alumni community, making BCS more like a tourist town specifically during those events. For BCS economy tourism remains as one of the major economic drivers. A study by Oxford Economics [95] supported the claim, stating, "Texas A\&M football is an economic engine, generating substantial business sales, employment, personal income, and local taxes" (p. 6).

Borrowing from Warren's [57] definition of community, BCS is an urban community where CBT participants interact individually and institutionally through an established system of tourism governance to achieve their common goals of socio-economic development, community cohesion, and well-being through tourism. Joint organizations such as Bryan-College Station Convention and Visitors Bureau and Bryan-College Station Chamber of Commerce represent and serve both cities in partnership with governing agencies in tourism such as cities and county and individual businesses including hotels and motels, community organizations, art and cultural groups, and so forth. Against this backdrop, BCS represents a specific case study of an urban CBT from a highly developed country, USA broadening the avenues of CBT research.

\subsection{Study Participants and Design}

Applying a purposive snowball sampling method [96], the study conducted semistructured interviews with tourism entrepreneurs and employees in BCS. The researcher/s also gleaned through secondary sources of information (such as published brochures /leaflets/annual reports/websites) from major players in BCS tourism governance such as the BCS Chamber of Commerce, BCS Convention and Visitors Bureau (CVB), cities, and County offices in BCS, along with individual participants' business websites/publications. The process helped to gather preliminary information regarding stakeholders' businesses and to provide guidance for upcoming interviews and site visits. The semi-structured qualitative research included both structured (closed ended) and open ended questions (at the end of interview). This mixed-method qualitative research combined both theoryand data-driven themes to augment the quality of study findings.

Research participants represented tourism related associations, city and county offices, community organizations, hotels, motels, and restaurants including owners of hotels and restaurants, executive and management level staff, and employees in frontline and backstage operations such as kitchen and room service (as detailed in Table 3). A total of 53 stakeholders were approached, and 40 of them were interviewed (13 refusals). Nine out of 10 backstage staff (mainly cooks/chefs and housekeepers) represented Hispanic and African-American ethnic minorities, while the other was White. The average duration of interviews was 45 min and took place between April 2015 and August 2016.

Regarding the ethnic background, 24 participants were Caucasian, eight Hispanic, and eight African-American, with the majority (62.5\%) being male. More than 55\% were 41-60 years old, and $62.5 \%$ possessed an undergraduate degree or more. Of the 40 respondents, 39 were BCS residents, except \#35, who was a resident of nearby city Navasota. 
Table 3. Number and category of study participants.

\begin{tabular}{|c|c|c|}
\hline Participant Names with Identifiers (Participant \#) & Participant Types & Category Total \\
\hline $\begin{array}{l}\text { BCS Convention and Visitors Bureau (CVB \#1), The Arts } \\
\text { Council (\#3), Downtown Bryan Association (DBA \#8), BCS } \\
\text { Chamber of Commerce (\#2), and Brazos Valley Lodging } \\
\text { Association (BVLA \#4) }\end{array}$ & Associations & 5 \\
\hline Eight restaurants (\#6, 11, 13, 14, 15, 18, 20 and 21) & Restaurants & 8 \\
\hline Five hotels and resorts $(\# 5,9,22,24$ and $\# 25)$ & Hotels \& resorts & 5 \\
\hline $\begin{array}{l}\text { Brazos Valley African American Historical Cultural Society } \\
\text { (BVAAHCS \#17), African-American Museum (AAM \#26), } \\
\text { African-American Church (AAC \#30), Fiesta Patrias (\#16), } \\
\text { Advent GX (\#12) }\end{array}$ & Community/cultural organizations & 5 \\
\hline $\begin{array}{l}\text { City of Bryan (\#7), City of College Station (\#28), Brazos } \\
\text { County Office (\#23), George Bush Presidential Library and } \\
\text { Museum (GBPLM \#19), and Texas A\&M University (TAMU) } \\
\text { Athletics Department (\#29) }\end{array}$ & Government offices & 5 \\
\hline Pedi cab (\#10), and Antiques / Art/Crafts shop (\#27) & Others & 2 \\
\hline $\begin{array}{l}\text { Five housekeeping staff at hotels (\#31, 33, 34, } 35 \text { and 36), and } \\
\text { Five hotel/restaurant kitchen staff }(\# 32,37,38,39 \text { and 40) }\end{array}$ & Backstage/housekeeping and kitchen staff & 10 \\
\hline Total Participants & & 40 \\
\hline
\end{tabular}

Source: Adapted from [97] (p. 8).

\subsection{Data Analysis}

The first author resided in the BCS area nearly for five years in connection with his $\mathrm{PhD}$ studies. During the study, the first author attended five cultural events and festivals in BCS including one of DBA's Thursday Morning meetings as a participant observer, which helped the author to enhance the cultural context of the study area. Following the completion of the first 10 interviews, the first author completed transcription of each interview verbatim. This early transcription process provided insights to improve upcoming interviews in terms of context and clarity (with remaining participants while starting the interviews). A process of iteration (moving back and forth between the literature and the data) was applied during data analysis for grasping a theory-driven scenario pertaining to the issues being explored. The data analysis process followed the seven analytic procedures suggested by Marshall and Rossman [98] (p. 206), which included (1) organizing the data, (2) immersion in the data, (3) generating categories and themes, (4) coding the data, (5) offering interpretations through analytic memos, (6) searching for alternative understandings, and (7) writing the report or other format for presenting the study. However, the data analysis also followed, in some instances, the direction by Hsieh and Shannon [99] that in directed qualitative content analysis, "codes are defined before and during data analysis", and "codes are derived from theory or relevant research findings" (p. 1286).

The study applied guidelines for coding and analysis as suggested by Marshall and Rossman [98] and Hsieh and Shannon [99], where research question/s specifically guided the emergence of codes for analysis (following structural analysis procedures). Further, an extensive literature review helped establish themes and issues for the analysis process. First, an independent line-by-line coding of each interview took place, leading to the development of common categories structured around the theme/s and research question/s. This systematic process of developing line-by-line codes helped minimize bias and knowledge of the field and the influence it might have had in the formation of codes and categories. Common categories derived were applied in the interpretation of the specific research question/s, then leading to the discussion. A comparison of codes and categories across various groups and individual participants was performed with a view of uncovering patterns of similarities or differences $[100,101]$ relating to the issues being explored. By applying a mixed qualitative data analysis approach, this research combined both 
theory- and data-driven themes (mixed of deductive and inductive methods) to support its robust findings.

\section{Findings/Results}

Guided by the research question, the study mainly explored distributive justice and difference principle from the theoretical perspectives of Rawls' $[29,30]$ Theory of Justice and endeavored to address the issue of ethic of care as advocated by Smith and Duffy [15] and several other scholars. Based on the responses received from all 40 participants relating to the research question, findings were categorized under two theory/research generated themes (and their sub-themes): (i) distribution of tourism revenues and benefits, and (ii) consideration to ethic of care followed by three data-driven themes (which emerged during data analysis).

Hotel occupancy tax (HOT) is one of the major sources of tourism revenues in BCS and relates to the mechanism of revenue distribution. Hotels, motels, tourist homes, lodges, inns, and bed and breakfast facilities, etc., are required (as per Texas State law) to collect HOT from the visitors for the twin cities and (Brazos) County office. The HOT money must be reallocated by the city and county offices for, among other reasons, tourism development and promotion, historical restoration and preservation, and/or establishment of a convention center [102]. At the time of research, BCS had a 15.75\% HOT, of which 7\% went to the city, $2 \%$ to the county, $6 \%$ to the state, and $0.75 \%$ to Kyle Field (rebuild).

\subsection{Distribution of Tourism Revenues and Benefits}

Mechanism for distribution of tourism revenues and its beneficiaries: The study found that a majority of participants $(n=22)$ across groups were aware how the HOT money was distributed; however, 18 participants including all 10 back-stage participants were not aware. Further, some participants expressed happiness on the effectiveness (\#20, 23, 32, and 34) of HOT money spending and functions of offices such as cities and counties, whereas a few (\#6 and 14) commented that more HOT money was allocated to the promotion of College Station than the City of Bryan.

Participants who knew how HOT money was distributed suggested that HOT revenue was distributed by the cities and county to offices such as CVB, the Arts Council, DBA, Research Valley Partnership (RVP), GBPLM, TAMU Athletics Department, Kyle Field rebuild, and the Expo Center, among others. The HOT funds were distributed to the City Parks and Recreation Departments (in BCS) and to the Chamber of Commerce for some specific programs (\#3).

Hotel participants (\#5, 9, 24, and 25) had detailed information on HOT distribution except one (\#22). Participant \#24 shared that there were some divergence of interests between the hoteliers and elected city officials regarding HOT money disbursement. For example, the City of College Station wanted to spend part of HOT money (\$10 million) on a Southeast Park development, which the hoteliers preferred to invest either on Veteran's Park to organize national sports events or to allocate to the CVB for destination marketing. In the community/cultural group, two participants (\#12 and 26) were aware of HOT distribution, whereas AAC (\#30) made a cautionary statement that HOT criteria carried a degree of power.

Government offices (\#7, 23, and 28) were at the distribution side of HOT (contrary to other stakeholders). The City of Bryan (\#7) received $1.5 \%$ out of general sales tax (GST), the County official (\#23) suggested that HOT distribution remained transparent, and community members were satisfied how the money was spent. HOT money contributed to the construction of the Expo Center (as people voted for), which drew visitors and money to BCS and contributed to its overall economy (\#23). The City of College Station official (\#28) said that $41 \%$ of the City's budget was generated through sales tax primarily contributed through tourism. The GBPLM (\#19) spent its HOT money on advertising and the TAMU Athletics Department (\#29) used it to repay facility use charges in Reed Arena for organizing events. Finally, the antique shop (\#27) in Bryan, Pedi cab (\#10), and two 
other participants (\#17 and 30) both had no knowledge of HOT distribution mechanism. None of the participants in the back-stage group (\#31-40) had any information relating to HOT distribution mechanisms, but two participants (\#32 and 34) guessed that distribution should be fair. Non-public relations and non-outside participation requirements for the jobs were one of the reasons that many backstage participants lacked information relating to HOT spending (as some participants suggested).

Stakeholder influence in the distribution of tourism revenue and benefits: The study showed that stakeholders played a significant role in the distribution of tourism revenues by submitting proposals or through participation in HOT discussions. Two participants (\#1 and 2) suggested they were influential in obstructing the passage of legislation otherwise allowing cities to use HOT money for buying lands. However, the City of Bryan official told to the first author later that the city hardly had a plan of that nature, nor did it intend to draft that kind of legislation. One hotel participant (\#24) shared that hoteliers protested the potential allocation of $\$ 10$ million HOT money by the City of College Station for the development of a Southeast Park, though the city official later clarified the proposal was being reviewed and they listened to and evaluated stakeholders' inputs before making program decisions. It seems that stakeholders tried to find common ground for conflicting issues. Participants (\#1, 2, and 8) emphasized that the working collaboration between the CVB and BCS Chamber of Commerce effectively worked in retaining Texas A\&M football from being relocated to Houston during the Kyle Field expansion, supposedly saving BCS businesses.

Financial incentives to locals and to ethnic minorities to run tourism business: The study found the majority $(n=26)$ of study participants (including the cities and county offices) suggested there were no such policies or financial incentives to locals and for ethnic minorities for tourism related businesses, except a few incentives from associations and tax-breaks offered by the cities (\#1 \& 12). The Chamber of Commerce launched a reward program for historically under-utilized businesses (HUB) and it operated a month-long Youth Leadership Program/Scholarship (for juniors in high school) targeting economically challenged youth (though application was open to all). The City of College Station and the Lodging Association participants informed that the U.S. Small Business Administration (U.S. SBA) could have incentives for startup for low-income and small-scale businesses. Festival grants from the CVB and the Arts Council helped event celebrations for all ethnic groups. The Brazos County official explained that increase in tourism could be considered as an incentive, as it generated more earnings for cities and counties, and helped decrease resident taxes, which equally benefitted low income people, too.

At least 19 participants conferred that they have seen tourism businesses such as hotels, motels, and restaurants operated by ethnic minorities including Asians, Hispanics, and African-Americans, excepting a few (\#31, 34, 35, and 36), who have not seen such businesses run by ethnic minorities. Some participants (\#15,18, and 28) opined that equal competitive conditions were needed, and incentives to one group would not be fair to another. One restaurant participant \#18 suggested incentives existed for new businesses such as Santa's Wonderland, which attracted visitors to BCS. One hotel participant (\#24) provided a reference of a protest where 40 hotels strongly opposed the incentives to one business (Atlas Hotel, LP, in Bryan was granted $\$ 7$ million by the City of Bryan in the past), on the grounds of being not fair or competitive. The city official had clarified that incentives were given following the policy decisions to foster overall economic development in Bryan.

A statement by participants (\#24, 30, 32, 33, and 39) suggesting an absence of a single hotel in BCS owned by the African-American community provided room for further exploration, as two participants (\#24 and 30) linked it to historic discrimination and racism, and participant (\#30) added that administrative criteria and scrutiny did not facilitate African-Americans well to establish or be successful in business. Two housekeeping participants (\#39 and 40) said such financial support was important, as some businesses may need start-up money, but it should be equal to all (\#33). 
Stakeholders' perception of fairness of tourism revenue distribution: The study found that stakeholders' perception of HOT money (tourism revenue) distribution was highly positive. For 13 participants, it was fair and transparent, and some agreed promotions launched by the CVB and DBA were fairer and more accountable (\#14), while others were not sure if they received a fair share (\#21) or had no idea/comment how it was distributed (\#24 and 29). Others opined it could be improved though sharing. It is worth mentioning that 10 back-stage staff expressed no opinions on those issues. All association and hotel participants and a majority of restaurant participants (\#11,13,14,15, and 18) believed a fair distribution system was in place and they enjoyed benefits in a fair manner. Fiesta Patrias (\#16) looked for more financial support and visitors' education, and the AAM (\#26) shared they received no invitation for HOT distribution discussions (though such meetings are public), but the organization was satisfied with the way HOT money was distributed. The Advent GX (\#12) asserted that a just system prevailed regarding the distribution of costs and benefits. Government offices also found it to be fair. The City of College Station official (\#28) shared that HOT distribution remained justifiable (not perfectly equitable). The Brazos County official (\#23) suggested there was transparency in HOT distribution, and the community remained satisfied with the nature of HOT distribution. In general, distribution of tourism revenues/economic benefits [11,12] was perceived to be fair (meeting one of the criteria of CBT success), and a majority of stakeholders in HOT receiving groups agreed to this statement.

\subsection{Consideration to Ethic of Care}

Living standards and wages of tourism workers: The study explored and examined the living standards and wages of tourism employees and found that almost all participants $(n=34)$ across groups agreed tourism workers received an average or above the average salary, but a few shared it was not enough for kitchen/housekeeping staff (\#3,11,16, and 24) or could be improved to better support the whole family (\#3, 16, 24, 30, 33, 34, 35, and 36). The CVB participant (\#1) stated that BCS frontline staff received a standard pay, but she was not sure of the back-stage staff payroll. She stated:

I do not know on the lower back of the house type positions, ... I think that there is so much competition in our community that they have to pay them well to keep them.

Other associations' group participants (\#1, 2, and 8) stated they paid their staff a living or better wage, but The Arts Council (\#3) thought government agency staff were better paid, whereas staff in non-projects received below average pay. All respondents in the government offices suggested that people working in BCS tourism were well paid or received above average pay. Most participants from the restaurants (\#11, 13, 14, 15, 18 , 20, and 21), hotels (\#5, 9, 22, 24, and 25) and cultural groups (\#12,16, 17, and 30) suggested their workers earned higher than the industry average or above the minimum. Some participants associated pay with quality of service or performance levels (\#13, 21, and 24) and suggested their servers and bartenders earned a good amount through tips (\#11 and 14).

Hotels/restaurants (\#20, 22, 24, and 25) had internal staff training and development programs to improve quality. Back of the house staff were suggested to face fewer promotion opportunities than frontline staff (\#22). The Fiesta Patrias participant (\#16) suggested that waiters and lower-level jobs were affected harder without a raise in wages for the past seven years. With $\$ 700$ bi-weekly pays, those waiters and lower-level workers were marginalized, participant (\#16) added. The AAC (\#30 AAM) participant claimed wages were not on par with the revenue.

All participants in the backstage group (\#31-40, all ethnic minorities except \#31) received minimum wages/salaries (minimum $\$ 7.25$ per hour as required by law) or higher than minimum. Two respondents (\#31 and 36) asserted they were paid "pretty decent wages" and "get paid pretty good", though they thought it was not enough to support ( $\$ 10.40$ an hour for \#36) a family. Participants (\#32, 33, 34, 35, and 39) found their wages to 
be enough for a single person only and wanted to be paid more. Another common concern a majority of participants in the backstage group (\#31,32, 33, 34, 35, 36, 38, 39, and 40) remained that in a sharp contrast to football season (Home games of Texas A\&M), summer hotel occupancy in BCS during summer remained lower, thereby affecting summer weekly work hours (ranging between 15-30 h for housekeeping staff to 30-36 h for participants \#33, 35, and 36). According to the Living Wage Calculator [103] for Brazos County, TX, a single adult would require living wages of $\$ 10.99$ per hour compared to minimum wage of $\$ 7.25$ per hour (then in 2016). The study found that a majority of back-stage respondents (except \#38 \& 40) lived below the Living Wage Calculator standard, though they received higher than the minimum pay. Issues of living standards and wages specifically for backstage staff have been suggested to be addressed from the perspective of ethic of care [15].

All backstage participants (\#31-40) suggested their department/unit (some small in nature) offered less promotion opportunities. Based on participants' feedback (\#31, $32,34,37$, and 39), the study found that educational qualification, experience, skills, job sincerity, and training positively contributed to job promotion, and it was not linked to race or ethnicity. For example, one respondent (\#34-an African-American female) with some college education earned a career growth opportunity from housekeeper (HK) to HK supervisor after a year. A majority of housekeeping and kitchen participants were given on-the-job trainings by their hotels/workplaces (2-3 week long for kitchen staff), while some managers received out of city training (\#24 and 25). Backstage staff seemed to be behind in educational achievement; however, not recognizing the concerns of an integral part of the staff unit with an ethic of care (not understanding their concerns whether they experience being treated/paid/promoted well) has been argued to compromise ethical values in tourism $[15,21,85,87]$. Whether the staff have received a proper degree of ethic of care needs further research.

Resident benefits of tourism including the minority/economically disadvantaged groups: The study found that participants across all groups (\#1-30) and 8/10 backstage participants (\#31-40) highlighted various benefits of tourism to residents, including the ethnic minorities and economically disadvantaged people. The benefits included:

(i) City facilities and services upgradation and development spurred by GST and tourismIncluding Veteran's Park upgradation, access to facilities for kids, and free pre-natal and medical services, stated by 14 participants.

(ii) Enhancing quality of life and community attractiveness (\#1, 2, 3, 4, 8, 9, 13, 16, and 17).

(iii) Sales tax helping lower property taxes (\#1, 2, 3, 4, 7, 8, and 19); and increase in property values but reduction on resident taxes (\#12 and 30).

(iv) Multiplier economic effects of tourism, including benefits through game days and other events/festivals, more business (as more people came in) and economic benefits to everybody, retention of some local businesses and moving of other businesses to BCS, opportunities for sharing business with College Station (for Bryan), and tourism provided opportunities to meet new people (stated by 23 participants).

(v) Enhanced community pride/image, including appreciation of community history and pride; post visit promotion of BCS; and tourism making the town livelier, cleaner, more interesting, more accessible, and safer than 5-10 years ago, and some people showing interest to move to BCS (suggested by 10 participants).

(vi) Income and employment generation, including influx of cash/money, job creation, and economic growth (stated by 14 participants).

Associations (\#1, 2, 3, 4, and 8) and hotel group participants (\#5, 9, 22, 24, and 25) suggested that tourism brought same benefits to the minority community as other residents. Participants (\#11 and 14) stated that visitors loved local hospitality. The City of College Station believed all residents shared tourism benefits equitably.

Fostering cultural pride and respect for community/ethnic minorities through tourism: Preservation and promotion of culture and heritage remains central to ethic of care. Overwhelmingly, 36 study participants conferred that tourism contributed to the preservation and promotion of BCS through the hosting of numerous cultural events and festivals. Nu- 
merous events organized in BCS are centered on the "Spirit of Aggieland". The City of Bryan festival grants and matching funds for historic preservation were highly lauded by a majority of participants.

Participants across groups (\#8, 14, and 18) suggested that various festivals helped preserve and promote the cultural heritage of BCS. Other respondents (\#9, 15, 16, 20,21, and 25) suggested Texas A\&M University (TAMU) traditions and the Aggieland culture were the dominant factors for promoting BCS as a tourist destination, as agreed by respondents from the City of College Station and TAMU Athletics, respectively (\#28 and 29). The revival of downtown Bryan and its designation as a Downtown Cultural District (by the Texas Commission on the Arts in 2014) based on its history and heritage was acclaimed as a huge success (by participants \#9, 10,11,13, and 18). All cultural group participants joined by the hotel participants $(\# 5,22$, and 25) mentioned that festivals related to tourism including Texas Reds and Steaks Festival, Jazz and Blues Festivals, Fiestas Patrias, and The World Festival had significant contribution to enhancing cultural pride within the community. An Arts Council participant (\#3) stated that the Texas Reds Festival (2015) drew "over 20,000 tourists over two days ..." ". Eight $(8 / 10)$ backstage respondents underlined the important role culture and festivals played in drawing visitors to BCS.

Local residents and exhibitors perceived events and festivals as proper platforms for sharing and interacting with tourists, whereas visitors expressed respect for the natural/cultural quality and heritage, and an appreciation for the place visited [61,104]. Festivals were also credited as income generating events for the vendors and residents, and contributed to community cohesion by creating avenues for interactions and entertainment. A significant revelation of the study was that 12 participants across various groups explained that the Texas A\&M University culture and Aggieland Spirit reflected the rich cultural diversity and traditions of BCS. Connections built with TAMU, and maintenance of bonding with the Aggie Spirit, were considered as powerful pull factors in attracting TAMU's alumni and other visitors.

Educating tourists about the diverse history and culture of the BCS: Some of the principles of justice tourism such as building solidarity between guests and hosts and promoting mutual understanding, guided by a sense of equality, sharing, and respect [61], including meaningful engagement of tourists with residents, are said to be integral factors to both ethic of care and justice tourism [27,61].

Regarding educating tourists, there were mixed opinions, as some respondents assigned the job to the CVB, while others suggested TAMU played a key role in educating tourists. Most participants (24 of 30 not including backstage staff) agreed that they or their staff got directly or indirectly involved in informing visitors about the places to go, mustvisit eateries in town, and events not to be missed in BCS. All five hotel participants were active in educating tourists. All respondents in the cultural group were active in diverse activities including communication with visitors through partner restaurants, conducting tourists' tours, delivering lectures, grooming staff, and for AAM (\#26), showcasing a booth at Texas A\&M events. The GBPLM displayed different events in rack-cards and conducted a Hall of Champions tour (at Kyle Field), whereas the TAMU Athletics Department organized event venue tours. The Pedi cab participant (\#10) took the opportunity to discuss Texas A\&M's rich history and tradition with its customers. A restaurant participant (\#14) shared that local residents "are proud tour guides" of the community. Given the nature of their jobs and limited encounters with tourists, few backstage staff had opportunities for educating or providing information to tourists.

Study findings suggest that tourism stakeholders in BCS feel proud to share their history and heritage with incoming visitors. Some of the tourists appreciated locals / stakeholders as one of the friendliest hosts (as shared by respondents \#18 and 20), restaurant owners/staff received warm compliments from visitors (\#21), and visitors enjoyed having a quality time at BCS, and they appreciated the warm hospitality extended to them (\#13). A few respondents stated that visitors to BCS were highly impressed by the warm welcome spirit (e.g., Howdy! Culture) of the local employees including the local 
cuisine (\#6 and 23). Based on participants' responses, it can be suggested that the safe destination image coupled with the warm hospitality extended by tourism employees and residents made many tourists interested to revisit (16 participants suggested safe and/or rich hospitality), moving to $(\# 1,2,3,7,9$, and 17), or retiring (\#3, 8, and 17) to the BCS area.

\subsection{Data-Driven Themes}

At the end of each semi-structured interview, participants were asked the following open-ended question:

Do you want to add some aspects you think important but were not included/discussed in the questionnaire?

Based on participants' feedback, the following three data-driven themes emerged:

TAMU as a Driver of Tourism to BCS: Twenty-two respondents across various groups reported that Texas A\&M's sports (including home games) and other educational events attracted a large number of tourists to BCS. As discussed earlier, cities and County played a major role in the distribution of tourism revenue (HOT money) in partnership with CVB and other associations. However, views of some participants supported TAMU's role in tourism promotion, as participant (\#3) stated, "Because at the end of day, what really drives tourism here is Aggie football, and Texas A\&M ... " Insights coming from participants in the form of data-driven (emergent) themes suggest the need for a broader, collaborative governance in BCS, including TAMU.

TAMU Culture/Aggie Tradition Shapes BCS Culture: Fourteen participants across various groups emphasized that the TAMU Culture and Aggieland Spirit (Howdy!) reflected the rich cultural heritage and diversity of BCS, which were prominent factors in attracting its alumni and community. Texas A\&M Culture (Howdy! Aggie Spirit) emerged as a unifying factor, as many respondents (\#1, 3, 4, 9, 15, 16, 21, 24, 25, 28, and 29) highlighted the role of TAMU culture. Further, "A Dose of Aggie Tradition for Newcomers" also emerged as another sub-theme, as participants (\#9, 10, 11, 15, 19, 28, and 29) supported this statement in various ways.

Game-day Traffic Creates Temporary Social Disruption in BCS: Most of the respondents across various groups suggested that a warm, welcoming spirit to visitors prevailed in BCS, mainly due to Texas A\&M's culture. However, at least 16 participants across all groups suggested that game day traffic disrupted their routine activities. They took it as a natural phenomenon, and residents and stakeholders were rather for games, as they adapted to the game day traffic for economic gains (\#1, 2, 3, 4, 12, 21, 23, 29, 30, and 32). Stakeholders hence developed coping mechanisms such as leaving town or staying at home, visiting cinemas, zoos, parks, or malls with children or family members (\#1, 2, 3, 4, 13, 23, 28, 29, and 30) on game days.

\section{Discussion}

Governance seems to have an important role in addressing the issues of justice, ethics, and equity, which have been suggested to need further research $[10,15,20,21,27,28]$ in sustainable tourism research and practices, including CBT. Guided by the theoretical and research-driven insights of this study, this discussion examines the issues of justice, ethics, and equity in the domain of governance relating to BCS tourism.

Stakeholders expressed a great sense of satisfaction related to the distribution of tourism revenues and benefits (HOT). Resident/stakeholder satisfaction has been recommended as one of the critical success factors of CBT $[49,61]$. However, concerns expressed relating to the incentives offered to a hotel in Bryan and stakeholders' protest to the City of College Station's proposal to develop Southeast Park through HOT money indicated a need for a better collaboration among stakeholders. The incentives granted to a new hotel in Bryan were of grave concern for other hoteliers, as respondent (\#24) stated, "I'm sure they'll (City of Bryan) remember forty hoteliers showing up in red shirts." Upon the researcher's request, the City of Bryan official clarified that the city had taken such steps following the policy decisions to boost economic development in Bryan. No doubt, those in 
governance sometimes need to look into larger benefits for the entire community; however, consensus, as suggested by Choi and Sirakaya [105], rather than conflict [72] has been suggested to drive better results in CBT settings. Further, a few participants (\#6 and 14) expressed dissatisfaction that the CVB put higher importance on promoting College Station and its sports, rather than Bryan and its culture. College Station received a bigger share of promotion due to higher contribution from College Station hoteliers to the HOT funding, which the CVB participant suggested was a standard procedure. However, the suggestions from participants require consideration for future planning. It is worth mentioning that governance and management of tourist destinations entails a complex network of stakeholders. Therefore, as suggested by Valeri and Baggio [106,107], the inclusion of current research insights including social network analysis (SNA) in the tourism planning stage could be helpful for BCS destination managers in enhancing stakeholder relationships, defining their roles, and improving mechanisms for service deliveries.

Regarding the provision of financial incentives to locals to run tourism-related businesses or for minority-operated businesses, the study observed some practical difficulties. The foundation of the liberal democratic regime in the U.S. ensures equal individual liberty and freedom to all, and rejects all types of discriminations or incentives to one group. For example, federal EEO provisions help ensure that persons cannot be discriminated on the basis of race, color, religion, sex, national origin, disability, or age. This could be the reason a majority of participants echoed the spirit of EEO. Theoretically, EEO is the ultimate goal societies strive to achieve, but during implementation it creates a potential to leave the poor poorer and vice-versa. Several instances of systemic racism and discrimination abound in the US. For example, in an examination of Black American entrepreneurship, Gold [108] revealed that race-based disadvantages included "low level of earning, lack of wealth, poor education, lack of experience in a family business, and difficulty in getting a loan" (p. 1712). This suggests that practices of systemic racism are still prevalent in the US. Though a majority of participants, including backstage participants, emphasized a level playing field; a few (\#31, 34, 39 \& 40) suggested financial incentives would better facilitate a startup business, though not based on race or ethnicity. It seems, those in tourism governance including cities could address such issues in partnership with some financing institutions or U.S. SBA. U.S. SBA seems to offer small business loans and preferences for historically underutilized businesses (HUB). In other parts of the world, there are examples such as Fair Trade in Tourism South Africa (FTTSA) where "historically disadvantaged individual (HDIs) are equitably represented in decision-making structures, including but not limited to top management" [93] (p. 740). These provisions seem to empower targeted disadvantaged groups in other countries; however, it may not stand a chance of equal applicability in BCS, Texas. With a reference to tourism development issues from the Third World countries, Crick [109] stated that "benefits from tourism unlike water, tend to flow uphill ... but the profits go to the elites-those already wealthy, and those with political influence ... the poor find themselves unable to tap the flow of resources" (p. 317). Crick's [109] statement holds significance for BCS to some extend where some disadvantaged people (e.g., ethnic minorities) seem to be affected from full participation in tourism businesses owing to the factors of historical discrimination as some respondents (\#24, 30, 32, 33 \& 39) have not seen a single hotel in BCS owned by an African-American. In a similar study, Blanchflower, Levine, and Zimmerman [110] found that "black-owned small businesses are about twice as likely to be denied credit even after controlling for differences in creditworthiness and other factors" (p. 930). Blackstock [58] also identified inclusion of social justice and local empowerment as challenges to CBT success.

Measured from the lenses of Rawls' Theory of Justice [29] and Justice as Fairness: A restatement [30] people from ethnic minorities and economically disadvantaged communities are enjoying the fundamental rights of equal liberties, and equal opportunities as guaranteed by the open, liberal democracy of the US and as championed in Rawls' two principles of justice. However, in the implementation side, the difference principle, that economic inequalities are acceptable provided the greatest benefit for the least-advantaged members 
of society are ensured, seems to face challenges for the current setting. The observation that Rawls' account of "distributive justice that is widely, though (he later admitted) not universally applicable" [15] (p. 99) seems relevant here. However, Smith and Duffy [15] mentioned Rawls' Justice as Fairness provides an objective way of measuring the competing notions of justice employed by different social groups in varying social contexts. Further, they believed Rawls' account "remains culturally relative (to modern Western societies) rather than universal" [15] (p. 101). This seems worth consideration for BCS tourism as the expenditure from tourism revenues by the cities to maintain and build public services and facilities including education, police, fire services, health, roads and transportation, parks and recreation, etc. can also be considered "all-benefitting" expenses, which all city residents including the economically disadvantaged can enjoy. This is similar to Lee and Jan [111] who asserted that CBT development "increases the number of facilities, roads, parks, and recreational and cultural attractions, which benefits residents' quality of life and respects their culture" (p. 368).

From the perspectives of ethic of care the study findings suggested that tourism employees in BCS enjoyed ethic of care in general as they were paid at least minimum or higher for their work. All businesses, small to large, ensured their staff were paid at least minimum as mandated by the law or above average or higher depending on staff skills. Results suggested that a majority of backstage staff faced reduced weekly work-hours in the summer; though they were paid minimum wages or higher, which was not close to the standard set by the Living Wage Calculator [103]. Living wage has been defined as a decent wage, as "it affords the earner and her or his family the most basic costs of living without need for government support or poverty programs" [103] (para. 1). This definition seems highly relevant in terms of ethic of care how the wages backstage workers earn from their jobs are supporting their livelihoods. In this study, a majority of backstage participants suggested that their wages could have been made better to support their families, or their summer work hours could have been increased. This is an area that requires more collaboration and coordination among accountable agencies in tourism governance to unearth new possibilities how those unsung backstage employees were ensured a living wage or compensated for summer work-hour losses. Smith and Duffy [15] suggested paying attention to ethic of care and justice to make tourism businesses sustainable, and Shiva [112] contended that sustainability meant beyond "bearing up" and developing a caring attitude to others while considering their needs.

The study also found staff promotion to be more problematic for housekeeping staff compared to front office or other departments, which relates to their ethic of care. It can be surmised that low morale arising from lack of promotion and bare minimum pay can have adverse impacts on business output; therefore, an ethic of care in addressing staff issues related to promotions or pay raises (though not easy and simple) can be recommended, as supported in many scholarly works $[15,21,85,87]$. This seems to be another critical issue for BCS tourism to consider in relations to justice, ethics, and equity.

Other positive factors participants suggested relating to an ethic of care remained that a significant flow of visitors from outside the community drawn by college sports and educational events helped enhance the destination image of BCS. They suggested this enhanced their living standards due to added city facilities and additional incomes, and many visitors showed interests to retire, relocate business, and revisit BCS in the future. This indicated a strong sense of mutual understanding and respect among the community, residents, and visitors (as shared by many participants), fulfilling a requirement for justice/ethical tourism [27,61]. Another positive side of BCS tourism remained that not a single respondent indicated any adverse impacts of tourism including vandalism, littering, or negative cultural impacts, as faced by many travel destinations [113].

Another issue the study explored was ethic of care where tourism made remarkable contribution to enhance community pride and respect for the diverse cultural groups and their heritage. A system of support through HOT funding facilitated the celebration of various ethnic festivals. All participants the researcher spoke to during events expressed 
satisfaction with these festivals and suggested that festivals reflected cultural and economic importance and fostered community cohesion, one of the criteria outlined for CBT success $[60,61,65]$. Moreover, some participants suggested that Texas A\&M's Aggieland or Howdy! Culture served as a unifying factor in the revival and promotion of the BCS culture. Similarly, Lee and Jan [111] stated the use of CBT practices can revive local culture and traditions by showcasing their celebrations to tourists. This is an instance how tourism and sports tourism have been intertwined in BCS to boost economy and promote cultural preservation.

As mentioned earlier, a few new data-driven themes emerged in the study. A significant number of respondents suggested that Texas A\&M University was one of the major drivers of tourism to BCS, and that A\&M sports benefitted BCS businesses and the community. This finding seems in agreement with Oxford Economics' [95] statement that "Texas A\&M football is an economic engine, generating substantial business sales, employment, personal income, and local taxes" (p. 6). Another report regarding the hotel occupancy, average daily rate (ADR), and revenue per available room (REV PAR) for College Station compiled by STR, Inc. Hendersonville, TN, USA [114] supports Oxford Economics' [95] findings that home games substantially contributed to the BCS economy through high hotel occupancy during game days (September through November) with high ADR and high REV PAR earned by the hotels (for details see [20] (pp. 286-289).

To conclude, as opposed to other studies including [115], the findings of the Oxford Economics [95] and STR Inc. [114] reflected the potential suggestions of this research that Texas A\&M football is a key factor to drive tourism to BCS; it creates economic opportunities in the community and helps minimize the gap of economic inequity by creating additional jobs. Following Texas A\&M's entry to the Southeastern Conference (SEC) in 2012 and viewership capacity added to Kyle Field, the economic impact of TAMU college football has the potential to increase drastically. Without doubt, TAMU Culture has significantly shaped BCS Culture, and social disruption of game day traffic is a temporary phenomenon that residents have acknowledged for economic gains. One participant (\#30) described the benefits and burdens of the events as:

"If you want wealth and development, you want to have revenue, you're going to have cows, you're going to have to have manure. You can't have one without the other."

\section{Practical Implications of the Research}

The study presented an integrated framework of SCBT identifying some underrepresented issues in the dimension of governance such as ethics, equitable distribution of benefits and burdens, respect and recognition for diverse values, and distributive justice benefitting disadvantaged populations, among others. The results reemphasized the suggestions of some early and current scholarly works $[10,20,21,27,28,80-83]$ by finding that CBT/ST operations can likely be more sustainable if issues related to justice, ethics, and equity are taken into consideration, while addressing potential benefits for economically disadvantaged persons. Therefore, it is believed the study has implications for those responsible in tourism planning/governance to develop facilitating provisions for the disadvantaged. Suggestions have been made to resolve some of the issues through capacity building, business ownership, empowerment, and with a broader and proactive form of governance, which engages and facilitates tourism stakeholders, specifically considering the needs of ethnic minorities and disadvantaged communities.

The integrated framework of SCBT, which was drawn from a systematic review of sustainable tourism and community-based tourism criteria and was applied for exploratory research in BCS, TX, can have implications for future research and practice. CBT has been utilized around the world to assist communities in improving their socio-economic and overall community well-being. However, limited CBT studies have been conducted in the USA. For example, Lo and Janta [116] present a chronology of CBT projects from 16 countries in Africa, Asia, Latin America, and Oceania (including Australia), and a reference from North America is missing (though the reason is not stated). Further, in a review 
of CBT and Rural Tourism, Zielinski, Jeong, Kim, and B Milanés [117] brought up 103 case studies from different parts of the world, where several case studies appeared from other developed nations such as Canada, Australia, and Spain, and just one case study appeared from the USA. This suggests that while CBT and/or rural tourism have remained in practice in the US for a long time, they have not drawn much attention in mainstream CBT discussions. Viewed from this perspective, the current research holds the potential of sharing more information on CBT practices from a developed economy. In the context when Jamal and Camargo [81] expressed concern on the worrisome state of "how little justice is studied in tourism studies" (p. 207) and Jamal and Higham [82] asserted the infancy stage of justice and tourism research requiring more "research and praxis to build a robust knowledge base and weave tighter just tourism futures" (p. 155), this research undoubtedly makes a new contribution to the field.

Further, owing to the vulnerability of the sustainable tourism paradigm amidst the setting of open-market economy and liberal democracy such as the United States, this research offers suggestions for making tourism governance more proactive, collaborative, and facilitative to better address the issues of justice, ethics, and equity and to contribute to sustainable tourism development. The authors believe this research contributes to the field by enhancing the existing body of knowledge and by addressing some of the gaps in sustainable-community based tourism. Thus, the research also lays a foundation for future research relating to SCBT.

\section{Recommendations}

Based on the aforementioned findings and discussion, likely courses of action offered by the respondents of the study and the body of information and knowledge existing in the field, the study proposed some recommendations. Justice, ethics, and equity have consistently been found to be integral to STD; however, futuristic recommendations offered on such issues could be suggestive only (rather than prescriptive ones), since tourism operations differ in various geographical, socio-cultural, and economic contexts. Smith and Duffy [15] commented that whether the scale of tourism developments are "good" or "bad" is morally charged (p. 2); therefore, it will be difficult to offer straight-forward recommendations and alternatives on ethical and justice issues pertaining to tourism development. However, any scholarly debate and new knowledge forwarded on such critical issues could be helpful in interpreting and communicating why some of the measures work and some do not in a given context. Therefore, the suggestions offered through this study may be valuable specifically for those in BCS tourism governance to better manage tourism, and they may provide a reference for other SCBT practitioners and researchers.

Need to incorporate TAMU as a part of tourism governance: While making suggestions for improvements, a significant number of participants outlined the influential role of Texas A\&M sports and academic events in bringing tourists to BCS. Further, other participants stated that connections with Texas A\&M, including bonding with the Aggie Spirit (Howdy!), served as powerful motivators in attracting its alumni and community to BCS. Feedback from participants suggest the need for incorporating Texas A\&M as a part of tourism governance for holistic and strategic tourism planning. This could be a contributing factor in establishing BCS as a year-round travel destination and helping to support jobs and equity issues.

Need for more facilitative and enterprising governance: The study found that a majority of participants $(n=26)$ stated that there were no such policies or financial incentives for locals and for ethnic minorities for tourism related businesses, excepting a few incentives from associations and tax breaks offered by the cities. Further, support for a level-playing field was categorically emphasized by a few participants. However, there were a few housekeeping participants (\#39 and 40) who said some financial support from government was important, as some enterprises may need start-up funds, but it should be equal to all (\#33). This indicates the need for governance to come forward with some incentives (though equitable), which could facilitate tourism business ownership (such as hotels) 
by some ethnic minorities (e.g., African-Americans). There are examples in other developed countries such as Australia where a host of government-assistance packages remain available for starting a business for Indigenous people [118]. Organizing/facilitating some informative or entrepreneurship development related workshops regarding the existing or potential support mechanisms through the Chamber of Commerce or U.S. SBA may improve opportunities for those who lack resources and information, and it may help develop new entrepreneurship. Absence of a single hotel owned by the African-American community in BCS, statements from two participants (\#24 and 30) linking historic discrimination and racism, and a participant (\#30) adding administrative criteria and scrutiny as reasons behind such status suggest the need for tourism governance to plan for equitable investment promotion in tourism to create and maintain a just and equitable society, as propounded by Rawls' [29] in his Theory of Justice.

Empowering the community through capacity building: Community empowerment has consistently been argued to be an integral factor of CBT success, including support to individuals and firms for enhancing job related capacity/skills through trainings. As discussed earlier, backstage staff representing ethnic minorities including Hispanics and African-Americans were found to face career promotion challenges, and African-Americans were found to have no known hotel ownership in BCS.

If ethnic minorities including Hispanics and African-Americans and disadvantaged groups in BCS are to benefit from tourism, some sort of intervention and facilitation by governing bodies may be required to work out the issues of inequity and for creating a just society, as proposed by Rawls [29,30]. Varying levels and scales of governments specifically in developing countries facilitate and support communities through education and training for capacity building and to develop tourism entrepreneurial skills $[50,70,105]$. If the local BCS governments, through the application of knowledge-based platform of tourism, could replicate programs such as skills and entrepreneurship development in partnership with other agencies, NGOs, or local experts, it could trigger positively in addressing equity and justice issues by engaging more people in tourism and sharing tourism benefits. In free-market capitalist economies, governments are not typically in a position to offer preferences to specific ethnic groups as practiced in some socialist countries. However, organizing capacity development trainings targeting all economically disadvantaged groups could include all ethnic groups without discrimination and benefit all. Recommendations from Mtapuri and Giampiccoli [59] for forming strong partnerships with different agencies included government departments, private sector, and NGOs for capacity building and skills development, which seem highly relevant for BCS tourism governance and community. A prescription for CBT success from these authors may be helpful for BCS tourism governance to more successfully facilitate tourism. A statement by Rawls [30] that "a basic principle satisfying the difference principle rewards people, not for their place in that distribution, but for training and educating their endowments, and for putting them to work to contribute to others good as well as their own" (p. 75) holds significance in this context. Moving beyond sustainable tourism, such measures may contribute to developing equitable, stable, and sustainable communities.

Need for rewarding/incentivizing the corporate innovation for ethic of care: Ethic of care has been found to be an issue in BCS tourism, especially for backstage staff representing ethnic minorities. By law, cities and counties cannot move beyond guaranteeing minimum wages in their jurisdictions. However, those in tourism governance could possibly organize public recognition programs for businesses that adhere to an ethic of care for all staff including backstage staff. They could conduct staff satisfaction surveys for recognitions and address issues related to ethic of care (this sounds unusual, though, as guest satisfaction surveys remain common) by allocating funds. Allocation of funds may come through regular tourism revenues such as GST (not HOT money), and they can provide recognitions and awards to outstanding businesses that treat their staff with an ethic of care. It was discussed earlier that the hotel occupancy, ADR, and REV PAR of BCS hotels grew significantly coinciding with home game days. This seems a potential area where responsible agencies 
in tourism governance in BCS can engage in proactive dialogue with tourism businesses including hotels to somehow compensate backstage staff (for their reduced work-hours in summer) by emphasizing a sense of corporate social responsibility or addressing their career-growth related issues. According to Smith and Duffy [15] and Shiva [112], one of the measures of ethic of care can be expressed through showing concern or through a start of dialogue.

Establishing local shuttle services to diversify tourism locations in BCS: Other suggestions from participants relating to justice and equity likely require attention. A few respondents expressed dissatisfaction that College Station and its sports were given more preferences including marketing priority by CVB compared to Bryan and its culture, which could serve as guidelines for future planning by the cities and CVB/s (even for cooperative marketing in the future). Another area the participants expressed concern remained that given the lack of public transport or shuttle services, tourists were rather centered on major attractions in BCS such as Texas A\&M University, George Bush Presidential Library and Museum, Downtown Bryan, and Messina Hof. It seems that development of city-transport services or shuttle services could help more attractions and lengthen visitors' stay in BCS. This suggestion may not require immediate attention from the BCS governance, but may be important for future planning. Further, based on the success of events and festivals in BCS in drawing locals and regional tourists, creation of new events and festivals targeting new locations in BCS could help address seasonality issues while diversifying tourism benefits.

\section{Conclusions and Limitations}

Conclusion: This study reinforces that issues of justice, ethics, and equity remain salient for sustainable tourism development; however, they can pose implementation challenges. Many scholars including Bramwell [17], Springett and Redcliff [19], and Boluk, Cavaliere, and Higgins-Desbiolles [72] have stated that ST governance at various scales and levels has largely remained deficient in addressing issues pertaining to sustainable tourism development. This study explored the state of ST and CBT practices in BCS with reference to justice, ethics, and equity and proffered some alternatives to address them through collaborative tourism governance. This research proffered various practical recommendations for the success of CBT in BCS in particular and other CBT settings in general by mixing systematic literature review with an empirical study. Smith and Duffy [15] underlined "genuine sustainable development is always and everywhere about ethics" (p. 159); however, the authors suggested that it would be hard to find universal solutions for ethical/justice issues or theories; rather, applying ethical values in the context of tourism development can contribute to sustainable development and ensure community benefits. Taking insights from justice tourism as "both ethical and equitable" [61] (p. 104), this research explored justice, ethics, and equity issues in BCS tourism and linked them to a broader spectrum of SCBT.

Limitations: One of the limitations of the current study is that it includes only the tourism stakeholders (not tourists and residents) in two adjoining towns of BCS. The views expressed by respondents working as business owners/managers or staffs representing various properties possibly relate more to their individual businesses such as hotels and restaurants and may not reflect the whole spectrum of BCS tourism. Addition of other research participants including visitors/tourists to BCS and residents (other than the business owners/employees interviewed) could have given the issues being explored a wider representation, which future studies may address. This study borrowed some of the criteria of ST/CBT applied in the settings of socialist democracies, which face some implementation challenges in an open market, capitalist economy, and liberal democracy such as the United States. Policy guidelines and popular practices of "Equal Employment Opportunity" (EEO) in the U.S. disapprove of job preferences for disadvantaged communities (as practiced in South Africa). Country specific variations in the political, social, and economic regimes and their corresponding practices make the issues of justice, ethics, and equity more complicated in relation to CBT practices, which underline the need for 
adapting to localized solutions. As a time-specific, two-year field-study comprising of only 40 research participants conducting semi-structured interviews, this research may fall short compared to other cross-sectional and longitudinal studies of similar nature. Therefore, this research has limitations in the transferability of its findings to other locations or situations. The use of mixed methods could broaden the validity, transferability, and generalizability of this type of research. Hence, it can be recommended that future researchers should explore and broaden this area of inquiry. This study also highlighted how issues of justice, ethics, and equity are critical to STD; however, given their complexity and gravity, each of these issues requires a separate and focused examination in the future in relation to tourism governance and sustainability. Given the research limitations, the researchers would like to suggest decision-making bodies in BCS tourism governance to complement the research findings with recent studies. However, given the context that issues of justice, ethics, and equity have remained less explored in relation to community based tourism in liberal democratic settings such as the United States, this research holds the potential of providing a reference to other developed, liberal economies as well as developing economies for comparing and contrasting the similarities and differences of SCBT practices.

Author Contributions: T.B.D. and J.F.P. both contributed for the preparation, review, and editing of this. All authors have read and agreed to the published version of the manuscript.

Funding: This research received no external funding.

Institutional Review Board Statement: IRB 2015-0149D, Human Research Protection Program, Texas A\&M University, College Station, TX, USA.

Informed Consent Statement: Informed consent was obtained from all subjects involved in the study.

Data Availability Statement: The data presented in this study are available in Tek B. Dangi's PhD dissertation.

Conflicts of Interest: The authors declare no conflict of interest.

\section{References}

1. Bramwell, B.; Lane, B. Sustainable tourism: An evolving global approach. J. Sustain. Tour. 1993, 1, 1-5. [CrossRef]

2. UNWTO; WTTC; EC. Agenda 21 for Travel and Tourism Industry: Towards Environmentally Sustainable Development; UNWTO; WTTC; Earth Council: London, UK, 1995; pp. 1-78.

3. Sharpley, R. Tourism and sustainable development: Exploring the theoretical divide. J. Sustain. Tour. 2000, 8, 1-19. [CrossRef]

4. United Nations Environment Program, (United Nations) World Tourism Organization (UNEP-UNWTO). Making Tourism more Sustainable—A Guide for Policy Makers; UNWTO: Madrid, Spain, 2005; Available online: http:/ /www.unep.fr/shared/ publications/pdf/DTIx0592xPA-TourismPolicyEN.pdf (accessed on 30 October 2020).

5. Blamey, R.K. Principles of ecotourism. In The Encyclopedia of Ecotourism; Weaver, D.B., Ed.; CABI Publishing: Cambridge, MA, USA, 2001; pp. 5-22.

6. Fennell, D.A. A content analysis of ecotourism definitions. Curr. Issues Tour. 2001, 4, 403-421. [CrossRef]

7. Miller, G.; Twining-Ward, L. Monitoring for a Sustainable Tourism Transition: The Challenge of Developing and Using Indicators; CABI Publishing: Cambridge, MA, USA, 2005.

8. Weaver, D. Community-based tourism as strategic dead-end. Tour. Recreat. Res. 2010, 35, 206-208. [CrossRef]

9. Goodwin, H. Taking Responsibility for Tourism; Goodfellow Publishers Limited: Woodeaton, UK, 2011; pp. 1-256.

10. Jamal, T.; Camargo, B.A.; Wilson, E. Critical omissions and new directions for sustainable tourism: A situated macro-micro approach. Sustainability 2013, 5, 4594-4613. [CrossRef]

11. Manyara, G.; Jones, E. Community-based tourism enterprises development in Kenya: An exploration of their potential as avenues of poverty reduction. J. Sustain. Tour. 2007, 15, 628-644. [CrossRef]

12. Lucchetti, V.G.; Font, X. Community Based Tourism: Critical Success Factors. Int. Cent. Responsible Tour. 2013, 1-20.

13. Garrod, B.; Fyall, A. Beyond the rhetoric of sustainable tourism? Tour. Manag. 1998, 19, 199-212. [CrossRef]

14. Liu, Z. Sustainable tourism development: A critique. J. Sustain. Tour. 2003, 11, 459-475. [CrossRef]

15. Smith, M.; Duffy, R. The Ethics of Tourism Development; Routledge: New York, NY, USA, 2003.

16. Gössling, S.; Hall, C.M.; Weaver, D. (Eds.) Sustainable Tourism Futures: Perspectives on Systems, Restructuring and Innovations; Routledge: New York, NY, USA, 2009.

17. Bramwell, B. Governance, the state and sustainable tourism: A political economy approach. J. Sustain. Tour. 2011, 19, 459-477. [CrossRef]

18. Dredge, D.; Jamal, T. Mobilities on the Gold Coast, Australia: Implications for destination governance and sustainable tourism. J. Sustain. Tour. 2013, 21, 557-579. [CrossRef] 
19. Springett, D.; Redcliff, M. Sustainable development: History and evolution of the concept. In Rutledge International Handbook of Sustainable Development; Redclift, M., Springett, D., Eds.; Routledge: New York, NY, USA, 2015; pp. 3-38.

20. Dangi, T.B. Towards a Robust Framework of Sustainable Community-based Tourism (SCBT): Exploring Destination Justice and Equity as a Part of Governance, a Case Study of Bryan-College Station, Texas. Ph.D. Thesis, Texas A\&M University, College Station, TX, USA, 2016.

21. Jamal, T.; Camargo, B.A. Sustainable tourism, justice and an ethic of care: Toward the just destination. J. Sustain. Tour. 2014, 22, 11-30. [CrossRef]

22. Farsari, I. The development of a conceptual model to support sustainable tourism policy in north Mediterranean destinations. J. Hosp. Mark. Manag. 2012, 21, 710-738. [CrossRef]

23. Stoddard, J.E.; Pollard, C.E.; Evans, M.R. The triple bottom line: A framework for sustainable tourism development. Int. J. Hosp. Tour. Adm. 2012, 13, 233-258. [CrossRef]

24. Roberts, S.; Tribe, J. Sustainability indicators for small tourism enterprises-An exploratory perspective. J. Sustain. Tour. 2008, 16, 575-594. [CrossRef]

25. Bricker, K.S.; Schultz, J. Sustainable tourism in the USA: A comparative look at the Global Sustainable Tourism Criteria. Tour. Recreat. Res. 2011, 36, 215-229. [CrossRef]

26. Global Sustainable Tourism Council (GSTC). GSTC Destination Criteria. Available online: https://www.gstcouncil.org/gstccriteria/gstc-destination-criteria / (accessed on 30 October 2020).

27. Higgins-Desbiolles, F. Justice tourism and alternative globalisation. J. Sustain. Tour. 2008, 16, 345-364. [CrossRef]

28. Higgins-Desbiolles, F. Justifying tourism: Justice through tourism. In Tourism and Inequality: Problems and Prospects; Cole, S., Morgan, N., Eds.; University of Wales Institute: Cardiff, UK, 2010; pp. 194-240.

29. Rawls, J. A Theory of Justice; The Belknap Press of Harvard University Press: Cambridge, MA, USA, 1971.

30. Rawls, J. Justice as Fairness: A Restatement; Kelly, E., Ed.; The Belknap Press of Harvard University: Cambridge, MA, USA, 2003.

31. Arksey, H.; O'Malley, L. Scoping studies: Towards a methodological framework. Int. J. Soc. Res. Meth. 2005, 8, 19-32. [CrossRef]

32. Grant, M.J.; Booth, A. A typology of reviews: An analysis of 14 review types and associated methodologies. Health Inf. Libr. J. 2009, 26, 91-108. [CrossRef]

33. Buckley, R. Sustainable tourism: Research and reality. Ann. Tour. Res. 2012, 39, 528-546. [CrossRef]

34. Dangi, T.B.; Jamal, T. An integrated approach to "sustainable community-based tourism". Sustainability 2016, 8, 475. [CrossRef]

35. United Nations World Commission on Environment and Development (UNWECD). Our Common Future; Oxford University Press: New York, NY, USA, 1987.

36. Hall, C.M.; Gossling, S.; Scott, D. (Eds.) The evolution of sustainable development and sustainable tourism. In The Rutledge Handbook of Tourism and Sustainability; Routledge: New York, NY, USA, 2015; pp. 15-35.

37. United Nations. United Nations Conference on the Human Environment. Available online: https://sustainabledevelopment.un. $\mathrm{org} /$ milestones/humanenvironment (accessed on 28 October 2020).

38. Hardy, A.; Beeton, R.J.; Pearson, L. Sustainable tourism: An overview of the concept and its position in relation to conceptualizations of tourism. J. Sustain. Tour. 2002, 10, 475-496. [CrossRef]

39. UNESCO. Convention Concerning the Protection of the World Cultural and Natural Heritage. Available online: http://whc. unesco.org/en/conventiontext/ (accessed on 28 October 2020).

40. Hall, C.M.; Gossling, S.; Scott, D. (Eds.) Tourism and sustainability: An introduction. In The Routledge Handbook of Tourism and Sustainability; Routledge: New York, NY, USA, 2015; pp. 1-12.

41. Carruthers, D. From opposition to orthodoxy: The remaking of sustainable development. In Debating the Earth: The Environmental Politics Reader, 2nd ed.; Dryzek, J.S., Scholsberg, D., Eds.; Oxford University Press: New York, NY, USA, 2005 ; pp. $285-300$.

42. UNDP-United Nations Development Program. Sustainable Development Goals. Available online: https://www.undp.org/ content/undp/en/home/sustainable-development-goals.html (accessed on 30 October 2020).

43. Mowforth, M.; Munt, I. Tourism and Sustainability: New Tourism in the Third World; Routledge: New York, NY, USA, 1998.

44. Graci, S.; Dodds, R. Sustainable Tourism in Island Destinations; Earthscan: Washington, DC, USA, 2010; pp. 1-225.

45. De Kadt, E. Tourism: Passport to Development? Perspectives on the Social and Cultural Effects of Tourism in Developing Countries; Oxford University Press: New York, NY, USA, 1979.

46. Byrd, E.T. Stakeholders in sustainable tourism development and their roles: Applying stakeholder theory to sustainable tourism development. Tour. Rev. 2007, 62, 6-13. [CrossRef]

47. Dangi, T.B.; Gribb, W.J. Sustainable ecotourism management and visitor experiences: Managing conflicting perspectives in Rocky Mountain National Park, USA. J. Ecotour. 2018, 17, 338-358. [CrossRef]

48. Jafari, J. The scientification of tourism. In Hosts and Guests Revisited: Tourism Issues of the 21st Century; Smith, V., Brent, M., Eds.; Cognizant Communication Corporation: New York, NY, USA, 2001; pp. 28-41.

49. Cole, S. Information and empowerment: The keys to achieving sustainable tourism. J. Sustain. Tour. 2006, 14, 629-644. [CrossRef]

50. Asker, S.A.; Boronyak, L.J.; Carrard, N.R.; Paddon, M. Effective Community based Tourism: A Best Practice Manual; APEC Tourism Working Group; Asia-Pacific Economic Cooperation: Singapore, 2010.

51. The International Ecotourism Society. What Is Ecotourism? 2015. Available online: https://ecotourism.org/what-is-ecotourism/ (accessed on 30 October 2020). 
52. National Geographic (2015-2020). Center for Sustainable Destinations. About Geotourism. Available online: https://www. nationalgeographic.com/maps/geotourism/ (accessed on 30 October 2020).

53. International Center for Responsible Tourism (ICRT). Responsible Tourism News-New Year. 2015. Available online: https: / / responsibletourismpartnership.org/?s=RESPONSIBLE+TOURISM+DEFINITION (accessed on 30 October 2020).

54. Netherlands Development Organization (SNV) Asia Pro-Poor Sustainable Tourism Network. A Toolkit for Monitoring and Managing Community-Based Tourism; SNV Asia Pro-Poor Sustainable Tourism Network and Griffith University: Queensland, Australia, 2007.

55. Hillery, G.A. Definitions of community: Areas of agreement. Rural Sociol. 1955, 20, 111-123.

56. Wilkinson, K.P. The Community in Rural America; Greenwood Publishing Group: New York, NY, USA, 1991 ; pp. 1-10.

57. Warren, R.L. Older and Newer Approaches to the community. In The Community in America; University Press of America, Inc.: Boston, Maryland, 1987; pp. 21-51.

58. Blackstock, K. A critical look at community based tourism. Comm. Dev. J. 2005, 40, 39-49. [CrossRef]

59. Mtapuri, O.; Giampiccoli, A. Towards a comprehensive model of community-based tourism development. S. Afr. Geog. J. 2016, 98, 154-168. [CrossRef]

60. Scheyvens, R. Ecotourism and the empowerment of local communities. Tour. Manag. 1999, 20, 245-249. [CrossRef]

61. Scheyvens, R. Tourism for Development: Empowering Communities; Prentice-Hall: Harlow, UK, 2002.

62. Joppe, M. Sustainable community tourism development revisited. Tour. Manag. 1996, 17, 475-479. [CrossRef]

63. Murphy, P.E. Tourism: A Community Approach; Methuen: New York, NY, USA, 1985.

64. Boley, B.B.; McGehee, N.G. Measuring empowerment: Developing and validating the Resident Empowerment through Tourism Scale (RETS). Tour. Manag. 2014, 45, 85-94. [CrossRef]

65. Boley, B.B.; McGehee, N.G.; Perdue, R.R.; Long, P. Empowerment and resident attitudes toward tourism: Strengthening the theoretical foundation through a Weberian lens. Ann. Tour. Res. 2014, 49, 33-50. [CrossRef]

66. Poitras, L.; Donald, G. Sustainable wine tourism: The host community perspective. J. Sustain. Tour. 2006, 14, 425-448. [CrossRef]

67. Billington, R.D.; Carter, N.; Kayamba, L. The practical application of sustainable tourism development principles: A case study of creating innovative place-making tourism strategies. Tour. Hosp. Res. 2008, 8, 37-43. [CrossRef]

68. Ellis, S.; Sheridan, L.M. The legacy of war for community-based tourism development: Learnings from Cambodia. Commun. Dev. J. 2014, 49, 129-142. [CrossRef]

69. Clarke, J. A framework of approaches to sustainable tourism. J. Sustain. Tour. 1997, 5, 224-233. [CrossRef]

70. Dodds, R.; Ali, A.; Galaski, K. Mobilizing knowledge: Determining key elements for success and pitfalls in developing community-based tourism. Curr. Issues Tour. 2018, 21, 1547-1568. [CrossRef]

71. Chettiparamb, A.; Kokkranikal, J. Responsible tourism and sustainability: The case of Kumarakom in Kerala, India. J. Policy Res. Tour. Leis. Events. 2012, 4, 302-326. [CrossRef]

72. Boluk, K.A.; Cavaliere, C.T.; Higgins-Desbiolles, F. A critical framework for interrogating the United Nations Sustainable Development Goals 2030 agenda in tourism. J. Sustain. Tour. 2019, 27, 847-864. [CrossRef]

73. Mahanti, A.; Manuel-Navarrete, D. From sustainable development to governance for sustainability. In Routledge International Handbook of Sustainable Development; Redclift, M., Springett, D., Eds.; Routledge: New York, NY, USA, 2015; pp. 416-428.

74. Johnston, C.S. Towards a theory of sustainability, sustainable development and sustainable tourism: Beijing's hutong neighbourhoods and sustainable tourism. J. Sustain. Tour. 2014, 22, 1-19. [CrossRef]

75. Siow May, L.; Abidin, Z.Z.; Nair, V.; Ramachandran, S.; Shuib, A. Developing criteria and indicators for responsible rural tourism in Taman Negara National Park (TNNP), Malaysia. Malays. For. 2011, 74, 143-156.

76. Puhakka, R.; Sarkki, S.; Cottrell, S.P.; Siikamäki, P. Local discourses and international initiatives: Sociocultural sustainability of tourism in Oulanka National Park, Finland. J. Sustain. Tour. 2009, 17, 529-549. [CrossRef]

77. Barke, M.; Towner, J. Learning from experience? Progress towards a sustainable future for tourism in the Central and Eastern Andalucian Littoral. J. Sustain. Tour. 2003, 11, 162-180. [CrossRef]

78. Pomering, A.; Noble, G.; Johnson, L.W. Conceptualising a contemporary marketing mix for sustainable tourism. J. Sustain. Tour. 2011, 19, 953-969. [CrossRef]

79. García-Melón, M.; Gómez-Navarro, T.; Acuña-Dutra, S. A combined ANP-delphi approach to evaluate sustainable tourism. Environ. Impact Assess. Rev. 2012, 34, 41-50. [CrossRef]

80. Jamal, T. Justice and Ethics in Tourism (Tourism, Environment and Development Series); Taylor and Francis: Abingdon-on-Thames, UK, 2019; Kindle Edition.

81. Jamal, T.; Camargo, B.A. Tourism governance and policy: Whither justice? Tour. Manag. Persp. 2018, 25, 205-208. [CrossRef]

82. Jamal, T.; Higham, J. Justice and ethics: Towards a new platform for tourism and sustainability. J. Sustain. Tour. 2020, $29,143-157$. [CrossRef]

83. Guia, J. Conceptualizing justice tourism and the promise of posthumanism. J. Sustain. Tour. 2020, 29, 501-519. [CrossRef]

84. Schianetz, K.; Kavanagh, L. Sustainability indicators for tourism destinations: A complex adaptive systems approach using systemic indicator systems. J. Sustain. Tour. 2008, 16, 601-628. [CrossRef]

85. Hultsman, J. Just tourism: An ethical framework. Ann. Tour. Res. 1995, 22, 553-567. [CrossRef]

86. Tribe, J. Education for ethical tourism action. J. Sustain. Tour. 2002, 10, 309-324. [CrossRef]

87. Macbeth, J. Towards an ethics platform for tourism. Ann. Tour. Res. 2005, 32, 962-984. [CrossRef] 
88. Lee, S.; Jamal, T. Environmental justice and environmental equity in tourism: Missing links to sustainability. J. Ecotour. 2008, 7, 44-67. [CrossRef]

89. Jamal, T.; Menzel, C. Good actions in tourism. In Philosophical Issues in Tourism; Tribe, J., Ed.; Channel View Publications: Bristol, UK, 2009; pp. 227-243.

90. Fennell, D.A. Tourism Ethics; Channel View Publications: Bristol, UK, 2006.

91. Peterson, T.R. Sharing the Earth: The Rhetoric of Sustainable Development; University of South Carolina Press: Columbia, SC, USA, 1997.

92. Moscardo, G. Exploring social representations of tourism planning: Issues for governance. J. Sustain. Tour. 2011, 19, 423-436. [CrossRef]

93. Strambach, S.; Surmeier, A. Knowledge dynamics in setting sustainable standards in tourism-the case of 'Fair Trade in Tourism South Africa'. Curr. Issues Tour. 2013, 16, 736-752. [CrossRef]

94. Hales, R.; Jamal, T. Environmental justice and tourism. In The Routledge Handbook of Tourism and Sustainability; Hall, C.M., Gossling, S., Scott, D., Eds.; Routledge: New York, NY, USA, 2015; pp. 151-164.

95. Oxford Economics-2012. The Economic Impact of Texas A\&M University Home Football Games. Available online: http: //wtaw.com/wp-content/uploads/2012/09/OxfordKyleFieldPpt.pdf (accessed on 30 October 2020).

96. Bernard, H.R. Social Research Methods: Qualitative and Quantitative Approaches; Sage Publications Inc.: Los Angeles, CA, USA, 2013.

97. Dangi, T.B. Exploring the intersections of emotional solidarity and ethic of care: An analysis of their synergistic contributions to sustainable community tourism development. Sustainability 2018, 10, 2713. [CrossRef]

98. Marshall, C.; Rossman, G.B. Designing Qualitative Research; Sage: Los Angeles, CA, USA, 2011.

99. Hsieh, H.F.; Shannon, S.E. Three approaches to qualitative content analysis. Qual. Health Res. 2005, 15, 1277-1288. [CrossRef]

100. Birks, M.; Mills, J. Grounded Theory; Sage: Los Angeles, CA, USA, 2011.

101. Bryant, A.; Charmaz, K. Grounded theory in historical perspective: An epistemological account. In The Sage Handbook of Grounded Theory; Bryant, A., Charmaz, K., Eds.; Sage: Los Angeles, CA, USA, 2010.

102. Texas Hotel \& Lodging Association (THLA). What Cities Need to Know to Administer Municipal Hotel Occupancy Taxes. 2014. Available online: http://www.cityofvidor.com/files/WhatCitiesNeedToKnow_HOT_FullVersion_Revised_2014.pdf (accessed on 30 October 2020).

103. Living Wage Action Coalition (LWAC). What's a Living Wage? Available online: www.livingwageaction.org/resources_lw.htm (accessed on 30 October 2020).

104. Woosnam, K.M.; Norman, W.C. Measuring residents' emotional solidarity with tourists: Scale development of Durkheim's theoretical constructs. J. Travel. Res. 2010, 49, 365-380. [CrossRef]

105. Choi, H.C.; Sirakaya, E. Sustainability indicators for managing community tourism. Tour. Manag. 2006, 27, 1274-1289. [CrossRef]

106. Valeri, M.; Baggio, R. Social network analysis: Organizational implications in tourism management. Int. J. Org. Anal. 2020. [CrossRef]

107. Valeri, M.; Baggio, R. Italian tourism intermediaries: A social network analysis exploration. Cur. Issues Tour. 2020, 1-14. [CrossRef]

108. Gold, S.J. A critical race theory approach to black American entrepreneurship. Ethn. Racial Stud. 2016, 39, 1697-1718. [CrossRef]

109. Crick, M. Representations of international tourism in the social sciences: Sun, sex, sights, savings, and servility. Annu. Rev. Anthr. 1989, 18, 307-344. [CrossRef]

110. Blanchflower, D.G.; Levine, P.B.; Zimmerman, D.J. Discrimination in the small-business credit market. Rev. Econom. Stat. 2003, 85, 930-943. [CrossRef]

111. Lee, T.H.; Jan, F.H. Can community-based tourism contribute to sustainable development? Evidence from residents' perceptions of the sustainability. Tour. Manag. 2019, 70, 368-380. [CrossRef]

112. Shiva, V. Staying Alive: Women, Ecology and Development; Zed Books: London, UK, 1989; pp. 1-234.

113. Hall, C.M.; Lew, A. Understanding and Managing Tourism Impacts: An. Integrated Approach; Routledge: New York, NY, USA, 2009.

114. STR, Inc. (“STR”); STR Global, Ltd. (“STRG”). Trend Report-College Station, TX Area Selected Properties; STR Corporate Headquarters: Hendersonville, TN, USA, 2016.

115. Coates, D.; Depken, C.A. Do College Football Games Pay for Themselves? The Impact of College Football Games on Local Sales tax Revenue. IDEAS. 2008. Available online: https:/ /ideas.repec.org/p/spe/wpaper/0802.html (accessed on 30 October 2020).

116. Lo, Y.C.; Janta, P. Resident's Perspective on Developing Community-Based Tourism-A Qualitative Study of Muen Ngoen Kong Community, Chiang Mai, Thailand. Front. Psycho. 2020, 11, 1493. [CrossRef]

117. Zielinski, S.; Jeong, Y.; Kim, S.I.; Milanés, C.B. Why community-based tourism and rural tourism in developing and developed nations are treated differently? A review. Sustainability 2020, 12, 5938. [CrossRef]

118. Fuller, D.; Buultjens, J.; Cummings, E. Ecotourism and indigenous micro-enterprise formation in northern Australia opportunities and constraints. Tour. Manag. 2005, 26, 891-904. [CrossRef] 